\title{
Cervical histology after routine ThinPrep or SurePath liquid-based cytology and computer-assisted reading in Denmark
}

\author{
Matejka Rebolj ${ }^{*, 1,6}$, Johanne Rask ${ }^{1,6}$, Marjolein van Ballegooijen ${ }^{2}$, Benny Kirschner ${ }^{3}$, Kirsten Rozemeijer ${ }^{2}$, \\ Jesper Bonde ${ }^{4,5}$, Carsten Rygaard ${ }^{4}$ and Elsebeth Lynge ${ }^{1}$ \\ ${ }^{1}$ Department of Public Health, University of Copenhagen, Øster Farimagsgade 5, Copenhagen 1014, Denmark; ${ }^{2}$ Department of \\ Public Health, Erasmus MC, 's-Gravendijkwal 230, Rotterdam 3015, the Netherlands; ${ }^{3}$ Department of Gynecology and Obstetrics, \\ Copenhagen University Hospital, Kettegård Alle 30, Hvidovre 2650, Denmark; ${ }^{4}$ Department of Pathology, Copenhagen University \\ Hospital, Kettegård Alle 30, Hvidovre 2650, Denmark and ${ }^{5}$ Clinical Research Centre, Copenhagen University Hospital, Kettegård \\ Alle 30, Hvidovre 2650, Denmark
}

Background: We compared the sensitivity and specificity of liquid-based cytology (LBC) and computer-assisted reading for SurePath/FocalPoint and ThinPrep with those of manually read conventional cytology in routine cervical screening in four Danish laboratories.

Methods: Using data from five nationwide registers, technological phases were identified by slide preparation, reading technique, and triage of borderline cytology. Trends in the detection of cervical intraepithelial neoplasia (CIN) were an indicator of the technology's relative sensitivity, and trends in false-positive tests an indicator of relative specificity.

Results: At 23-29 years, SurePath/FocalPoint statistically significantly increased the detection of $\geqslant$ CIN3 by $85 \%$ compared with manually read conventional cytology. The 11\% increase with ThinPrep was not significant. At 30-44 years, the increase with SurePath/FocalPoint was 58\%; the 16\% increase with ThinPrep was not significant. At 45-59 years, both technologies led to nonsignificant decreases in the detection. SurePath/FocalPoint doubled the frequency of false-positive tests at any age. With ThinPrep, these proportions remained the same at 23-29 years, but decreased by two-thirds at 45-59 years. In a fourth laboratory with continuous use of manually read conventional cytology, no such trends were seen.

Conclusions: The sensitivity and specificity of modern LBC and computer-assisted reading technologies may be brand- and agedependent.

In the past two decades, the classical Pap smear has been replaced by liquid-based cytology (LBC), whereas manual reading is now assisted by computer reading. At present, the cytology market is dominated by ThinPrep (Hologic, Bedford, MA, USA) and SurePath/FocalPoint (BD, Franklin Lakes, NJ, USA) technologies. The advantages of LBC include purified stains, cell monolayers, and the ability to run additional analyses on the same sample, for example, for human papillomavirus (HPV) or biomarker expression testing. Computer-assisted reading systems deselect normal samples and point cytologists to the most critical areas in suspect samples.

The use of the new technologies has also affected women. In two routine Danish laboratories, the switch to SurePath LBC significantly increased the proportions of abnormal cytological samples at age $<45$ years, and decreased them in older women (Barken et al, 2014; Rask et al, 2014). ThinPrep LBC in another

*Correspondence: Dr M Rebolj; E-mail: matejka.rebolj@regionh.dk
${ }^{6}$ These authors contributed equally to this work.

Received 20 April 2015; revised 10 August 2015; accepted 24 August 2015; published online 8 October 2015

(c) 2015 Cancer Research UK. All rights reserved 0007-0920/15 
Danish laboratory was associated with a decreased proportion of abnormal cytological samples at any age. This decrease was especially large around menopause, possibly because LBC makes neoplastic lesions more easily distinguished from, for example, atrophy. Computer-assisted reading technologies increased the proportions of abnormal cytology regardless of the brand and the woman's age.

These changes led to a different selection of women referred for further follow-up. The next question is, therefore, whether there was also a change in the detection of high-grade cervical intraepithelial neoplasia (CIN). Previous trials comparing LBC and/or computer-assisted reading to conventional methods led to conflicting results regarding the changed CIN detection; some suggested a statistically significantly decreased, some equal, and some a significantly increased detection (Arbyn et al, 2008; Kitchener et al, 2011a; Klug et al, 2013).

Based on routine screening data from four laboratories evaluating about one-third of all cytology in Denmark, we aimed to determine whether the age-specific changes in abnormal cytology described above led to changes in the detection of histologically confirmed high-grade CIN.

\section{MATERIALS AND METHODS}

Cervical screening has been undertaken in Denmark since the 1960s. In 1986, organised cytological screening at age 23-59 years was recommended every 3 years. Since 2007, women aged 50-65 years have been targeted every 5 years, whereas since 2012, women aged $\geqslant 60$ years can be 'checked out' of the programme following a negative HPV test result. Screening coverage has been around $75 \%$, with negligible regional variation.

Previously, we studied changes in the detection of atypical squamous cells of undetermined significance or worse ( $\geqslant$ ASCUS) following the introduction of LBC and computer-assisted reading technologies in 1998-2007 in Departments of Pathology of Copenhagen University Hospital Hvidovre, Hillerød Hospital, and Odense University Hospital (Table 1) (Barken et al, 2013; Rask et al, 2014). Department of Pathology of Roskilde County Hospital, retaining manually read conventional cytology, was used to study technology-independent changes, for example, changes in the background risk of cervical cancer. Each laboratory served welldefined catchment areas: Hvidovre laboratory received samples from Copenhagen and Frederiksberg Municipalities; Hillerød from Frederiksborg County; Roskilde from Roskilde County; and Odense from Funen County. The coverage rates of the target population were stable, as was the case-mix of samples (screening vs follow-up).

Data sources. We retrieved the information on the women's age and place of residence from the Danish Civil Registration System. Since 1968, every resident has been registered with a unique identification number (CPR number). Data on cervical cytology and biopsies including their diagnoses were obtained from the Pathology Data Bank (Patobank). We also retrieved data on conisations from the Patobank; since mid-1990s, conisations were most frequently undertaken as large loop excisions of the transformation zone and had a specific Danish Systematised Nomenclature of Medicine (SNOMED) code. Additional data on cervical treatments including conisations, destructive therapies, hysterectomies, excisions, and other less frequent types of treatment (Barken et al, 2012) were retrieved from (a) the National Patient Register where information on in-patient treatments and the associated diagnoses has been available since 1978, and on outpatient treatments since 1995, and from (b) the National Health Service Register containing non-diagnostic information on biopsies and cervical treatments undertaken by private gynaecologists since
1990. The Danish Cancer Register was used to obtain information on incident cervical cancers since 1943. Data were retrieved from the beginning of the registration until end of 2010 and were linked using the CPR number.

In the Patobank, diagnoses were registered using the SNOMED classification. Diagnoses were classified into Bethesda 2001 categories. An exception was made for Hvidovre (Barken et al, 2014), where samples from women aged $\geqslant 30$ years with an initial ASCUS diagnosis and a negative reflex HPV test were, during a limited time period, routinely downgraded to normal cytology. As these women were recommended for repeated testing despite the nominally normal diagnosis, we reclassified them as having ASCUS.

Technology phases. Laboratories were autonomous in making decisions regarding the technology and the combinations of slide preparation and reading technologies differed even between the laboratories that used the same brand. Consequently, data were analysed for each laboratory separately.

As described previously (Barken et al, 2013; Rask et al, 2014), technological phases were identified by slide preparation, reading technique, and triage of ASCUS at $\geqslant 30$ years. All piloting and implementation periods were excluded. 'Baseline' in phase 1 was defined for all laboratories as manual reading of conventional cytology with cytological triage of ASCUS. The Odense laboratory returned to manually read conventional cytology after a ThinPrep LBC pilot. Because the differences in the proportions of all studied end points were not statistically significant, data for pre- and postpilot periods were merged (excluding the pilot).

In phase 2, Hvidovre laboratory started using FocalPoint reading technology. FocalPoint Slide Profiler replaced manual reading, and the cutoff for no further review of normal samples was set to $50 \%$ following an internal pilot. The remaining samples were automatically divided into five quintiles of likelihood of abnormalities. In phase 3, SurePath LBC replaced conventional cytology, whereas the laboratory continued using FocalPoint Slide Profiler with a 50\% cutoff. This cutoff was changed to the manufacturer's recommended $25 \%$ in phase 4 , meaning that cytotechnicians and pathologists had to evaluate $75 \%$ instead of $50 \%$ of all samples. Additionally, cytology was replaced by HPV testing in triage of ASCUS at age $\geqslant 30$ years using Qiagen's Hybrid Capture 2 (HC2) assay. In phase 5, FocalPoint GS Imaging System was added, which, in the $75 \%$ of samples not automatically signed out by the FocalPoint Slide Profiler, guided the cytotechnicians through 16 preselected fields of view (most likely to contain abnormalities).

Hillerød laboratory closely followed the changes made in Hvidovre. In phase 2, it introduced FocalPoint Slide Profiler with the $50 \%$ cutoff, which was changed to $25 \%$ in phase 3 together with introducing SurePath LBC. In phase 4, FocalPoint GS Imaging System was added. Throughout the study period, ASCUS was triaged with cytology.

Odense laboratory started using ThinPrep technology in phase 2 when conventional cytology was replaced by LBC using ThinPrep Pap test in T3000 processor (Hologic). In phase 3, ThinPrep Imaging System (Hologic) including Imaging Pap Stain replaced conventional Pap stain and manual reading. The system guided the cytotechnician to 22 fields of view. Also here, cytology was used to triage ASCUS in all phases.

To determine potential trends in Roskilde, manually read conventional cytology data were analysed in arbitrary 3-year periods.

Inclusion criteria. We included samples taken from 1 January 1998 to 31 December 2007 at age 23-59 years, the target age until 2007. As an exception, we excluded year 2007 for Hillerød and Roskilde since a national administrative reorganisation led to changes in their catchment areas. Samples taken for follow-up of 
Table 1. Description of phases by laboratory

\begin{tabular}{|c|c|c|c|c|}
\hline $\begin{array}{l}\text { Laboratory } \\
\text { (county catchment area) } \\
\text { and phase }\end{array}$ & Period & Slide preparation & Reading technique & Triage \\
\hline \multicolumn{5}{|l|}{ Roskilde (Roskilde County) } \\
\hline & $\begin{array}{l}1 \text { January } 1998 \text { to } \\
31 \text { December } 2000\end{array}$ & & & \\
\hline Phase 2 & $\begin{array}{l}1 \text { January } 2001 \text { to } \\
31 \text { December } 2003\end{array}$ & As above & As above & As above \\
\hline Phase 3 & $\begin{array}{l}1 \text { January } 2004 \text { to } \\
31 \text { December } 2006\end{array}$ & As above & As above & As above \\
\hline \multicolumn{5}{|c|}{ Hvidovre (Copenhagen and Frederiksberg Municipalities) ${ }^{a}$} \\
\hline Phase 1 & $\begin{array}{l}1 \text { January } 1998 \text { to } \\
30 \text { September } 1999\end{array}$ & Conventional cytology & Manual & Cytology \\
\hline Phase 2 & $\begin{array}{l}1 \text { July } 2000 \text { to } \\
30 \text { April } 2002\end{array}$ & As above & $\begin{array}{l}\text { Computer-assisted (BD FocalPoint Slide } \\
\text { Profiler, } 50 \% \text { cutoff) }\end{array}$ & As above \\
\hline Phase 3 & $\begin{array}{l}1 \text { August } 2002 \text { to } \\
30 \text { April } 2005\end{array}$ & $\begin{array}{l}\text { LBC (SurePath Pap test, BD } \\
\text { PrepStain Slide Processor) }\end{array}$ & As above & As above \\
\hline Phase 4 & $\begin{array}{l}1 \text { October } 2005 \text { to } \\
30 \text { November } 2006\end{array}$ & As above & $\begin{array}{l}\text { Computer-assisted (BD FocalPoint Slide } \\
\text { Profiler, } 25 \% \text { cutoff) }\end{array}$ & $\begin{array}{l}\text { HPV DNA (Qiagen } \\
\text { Hybrid Capture 2) }\end{array}$ \\
\hline Phase 5 & $\begin{array}{l}1 \text { April } 2007 \text { to } \\
31 \text { December } 2007\end{array}$ & As above & $\begin{array}{l}\text { Computer-assisted (as above plus BD } \\
\text { FocalPoint GS Imaging System) }\end{array}$ & As above \\
\hline \multicolumn{5}{|c|}{ Hillerød (Frederiksborg County) ${ }^{c}$} \\
\hline Phase 1 & $\begin{array}{l}1 \text { January } 1998 \text { to } \\
31 \text { July } 2002\end{array}$ & Conventional cytology & Manual & Cytology \\
\hline Phase 2 & $\begin{array}{l}1 \text { September } 2002 \text { to } \\
31 \text { December } 2003\end{array}$ & As above & $\begin{array}{l}\text { Computer-assisted (BD FocalPoint Slide } \\
\text { Profiler, } 50 \% \text { cutoff) }\end{array}$ & As above \\
\hline Phase 3 & $\begin{array}{l}1 \text { October } 2004 \text { to } \\
31 \text { October } 2005\end{array}$ & $\begin{array}{l}\text { LBC (BD SurePath Pap test, } \\
\text { BD PrepStain Slide processor) }\end{array}$ & $\begin{array}{l}\text { Computer-assisted (BD FocalPoint Slide } \\
\text { Profiler, } 25 \% \text { cutoff) }\end{array}$ & As above \\
\hline Phase 4 & $\begin{array}{l}1 \text { February } 2006 \text { to } \\
31 \text { October } 2006\end{array}$ & As above & $\begin{array}{l}\text { Computer-assisted (as above plus BD } \\
\text { FocalPoint GS Imaging System) }\end{array}$ & As above \\
\hline \multicolumn{5}{|l|}{ Odense (Funen County) } \\
\hline Phase 1a & $\begin{array}{l}1 \text { January } 1998 \text { to } \\
31 \text { December } 1998\end{array}$ & Conventional cytology & Manual & Cytology \\
\hline Phase $1 b$ & $\begin{array}{l}1 \text { November } 1999 \text { to } \\
31 \text { May } 2001\end{array}$ & As above & As above & As above \\
\hline Phase 2 & $\begin{array}{l}1 \text { January } 2004 \text { to } \\
30 \text { September } 2004\end{array}$ & $\begin{array}{l}\text { LBC (Hologic ThinPrep Pap test, } \\
\text { T3000 Slide Processor) }\end{array}$ & As above & As above \\
\hline Phase 3 & $\begin{array}{l}1 \text { October } 2006 \text { to } \\
31 \text { December } 2007\end{array}$ & As above & $\begin{array}{l}\text { Computer-assisted (Hologic ThinPrep } \\
\text { Imaging System) }\end{array}$ & As above \\
\hline \multicolumn{5}{|c|}{$\begin{array}{l}\text { Abbreviations: ASCUS = atypical squamous cells of undetermined significance; HPV = human papillomavirus; LBC = liquid-based cytology. Note: All periods between phases represented } \\
\text { periods of piloting and implementation of the technology, and were excluded from the study. } \\
\text { a Owing to incomplete histological registration before } 2001 \text { for women residing in Frederiksberg Municipality, data were analysed separately by municipality (from phase } 1 \text { onwards for women } \\
\text { residing in Copenhagen Municipality, and for Frederiksberg Municipality only from phase } 2 \text { onwards). } \\
\text { bThis also signifies a change in the recommended follow-up. Whereas with cytological triage, all women with ASCUS were recommended for repeated testing at } 6 / 12 \text { months, they were } \\
\text { recommended for immediate colposcopy if HPV-positive, and for repeated testing in } 12 \text { months if HPV-negative. } \\
\text { cOwing to incomplete histological registration for women residing in Frederiksborg County, only data for samples taken from } 1 \text { January } 2003 \text { onwards were included in the analysis, that is, from } \\
\text { phase } 2 \text { onwards. }\end{array}$} \\
\hline
\end{tabular}

recent abnormalities were excluded. Previous analyses (Barken et al, 2013; Rask et al, 2014) used the same definitions.

The worst histological outcome was determined within 2.5 years after the abnormal cytological sample. Women who died or emigrated from Denmark during the follow-up were excluded. Some biopsies were evaluated by private pathologists who were historically not obliged to report their diagnostic data to the Patobank. Women were, therefore, also excluded if they lived in, or moved to, a county with inadequate histological registration in the Patobank, defined as registration of $<85 \%$ of all biopsies (Barken et al, 2012). This implies exclusion of samples from Hillerød before 1 January 2003, and from Hvidovre/Frederiksberg before 1 January 2001.

Samples taken for follow-up of recent abnormalities were those with a preceding cervical cancer diagnosis; CIN diagnosis or treatment in $\leqslant 10$ years; high-grade cervical squamous intraepithelial lesions or worse ( $\geqslant$ HSIL), inadequate cytology, or a positive HPV test result in the past 12 months; and inadequate/ negative histology, low-grade cervical intraepithelial lesions, or ASCUS in the past 15 months. The remaining were predominantly screening samples, taken either in organised or opportunistic settings. As the indication for sample taking was not registered, they may have also contained a small proportion of samples taken for investigation of symptoms. The proportion of the latter samples was assumed not to be associated with the technological phases.

Statistical analysis. ASCUS was the cutoff for abnormal cytology as it was the indication for further follow-up. The following end points were determined per 100 screening samples: detection of histologically confirmed CIN2 and $\geqslant \mathrm{CIN} 3$, number of CIN treatments (all indicators of cytology's sensitivity), detection of histologically confirmed $<\mathrm{CIN} 2$, and number of false-positive samples (indicators of specificity). False-positive samples were defined as $\geqslant$ ASCUS without $\geqslant$ CIN2 or $\geqslant$ CIN3 during follow-up (Rebolj et al, 2012). Cervical intraepithelial neoplasia treatments included all conisations (most frequently undertaken as large-loop excision of the transformation zone), and destructive therapies, hysterectomies, excisions, and other less frequent treatments if histological CIN of any grade was registered in the period between 
3 months before and 1 month after the treatment (Barken et al, 2012). We calculated the positive predictive value (PPV) for $\geqslant \mathrm{CIN} 2$ and $\geqslant \mathrm{CIN} 3$ as the number of detected lesions per 100 screening samples with an $\geqslant$ ASCUS diagnosis.

The main comparison was between manually read conventional cytology (baseline/phase 1) and full implementation of modern cytological technologies by end of 2007 (the last phase per laboratory). Per laboratory, we calculated relative proportions (RPs) of the observed end points in the final phase compared with the baseline. The data for the baseline situation were not available for Hvidovre/Frederiksberg and Hillerød, thus these laboratories did not contribute here. To assess the contribution of each change in technology, we also calculated RP comparing with the previous phase. We stratified the comparisons by age group (23-29, 30-44, and 45-59 years). The $95 \%$ confidence intervals (CI) for RP were calculated assuming log-normal distribution.

Proportions of $\geqslant$ ASCUS were a focus of previous publications (Barken et al, 2014; Rask et al, 2014), and were not further discussed here. Because for the present analysis the definition of the at-risk population excluded women whose histological outcomes could not be reliably determined, these proportions were tabulated anew. The proportions of women with $\geqslant$ ASCUS with and without the exclusion were similar.

\section{RESULTS}

Study population. In total, 674248 samples were included: 151135 from Roskilde, 283310 from Hvidovre/Copenhagen, 38831 from Hvidovre/Frederiksberg, 71915 from Hillerød, and 129057 from Odense (Table 2). Relatively few samples from counties with incomplete histological registration were excluded (Table A1), most often from Hvidovre serving the area with traditionally highest rates of migration to other counties. The age distribution and completeness of routine follow-up did not change substantially between phases in each laboratory. Most abnormal samples $(\geqslant 90 \%)$ had follow-up. The Roskilde, Odense, and Hillerød laboratories served a population with a higher average age than Hvidovre (Table A2).

Changes in the laboratory with continuous use of manually read conventional cytology. In Roskilde, few changes between the last and the first phase were observed (Table 3 and Figure 1: detection of $\geqslant \mathrm{CIN} 2$; Figure 2: detection of $<\mathrm{CIN} 2$; and Figure 3 : falsepositive tests). The changes were only significant for the proportions of false-positive tests and $<\mathrm{CIN} 2$ biopsies, particularly at 45-59 years. A more detailed phase-by-phase comparison by age revealed some fluctuations but no trends (Table A3).

Changes with SurePath technologies. In Hvidovre/Copenhagen, full implementation of SurePath/FocalPoint LBC and reading technologies compared with manually read conventional cytology was associated with a doubling of the frequency of all studied outcomes at 23-44 years, with the exception of a decreased PPV for $\geqslant \mathrm{CIN} 2 / \geqslant \mathrm{CIN} 3$. In older women, 45-59 years, the only statistically significant change was a doubling of the frequency of false-positive tests, and a corresponding decrease in the PPV.

The first step toward computer-assisted reading using a $50 \%$ cutoff on FocalPoint Slide Profiler (comparing phase 2 with phase 1, using conventional cytology and cytological triage of ASCUS in both phases) had little impact on the studied outcomes (Table A4). At 23-29 years, however, the frequency of $<\mathrm{CIN} 2$ biopsies and false-positive tests increased significantly by $10-30 \%$. At $45-59$ years, detection of $\geqslant \mathrm{CIN} 3$ statistically significantly decreased (by $36 \%$ ). The overall PPV for $\geqslant \mathrm{CIN} 2 / \geqslant \mathrm{CIN} 3$ decreased by $13 \%$.

SurePath LBC implementation (comparing phase 3 with phase 2, using FocalPoint Slide Profiler for reading with a $50 \%$ cutoff and cytological triage of ASCUS in both phases) was associated with a statistically significantly increased detection of $<$ CIN2, high-grade CIN, and the frequency of CIN treatments at 23-29 years, all by $30-40 \%$, and in the frequency of false-positive tests by $>50 \%$. The increases were slightly smaller at 30-44 years. In women around menopause, 45-59 years, the decreases in CIN detection and in false-positive tests after the introduction of LBC were generally not statistically significant.

After a change in the FocalPoint Slide Profiler's cutoff from 50 to $25 \%$, and a concurrent introduction of HPV triage for ASCUS (comparing phase 4 to phase 3 using SurePath LBC in both phases), statistically significant increases in all studied outcomes were observed at 23-44 years (by $\sim+20-30 \%$ ). At $45-59$ years, significantly increased frequency was observed for $<$ CIN2 biopsies $(+23 \%), \geqslant \mathrm{CIN} 3(+66 \%)$, and false-positive tests $(+73 \%)$.

The addition of FocalPoint GS Imaging System (comparing phase 5 with phase 4, using FocalPoint Slide Profiler with a 25\% cutoff, SurePath LBC, and HC2 triage of ASCUS in both phases) was associated with statistically insignificant increases in the frequency of most studied outcomes. However, at 30-59 years, the frequency of false-positive tests increased significantly (by $\sim+20 \%$ ), and so did the frequency of $<$ CIN2 biopsies at 2344 years $(+25-30 \%)$.

Similar patterns in the RP of the studied outcomes across phases were seen also at Hvidovre/Frederiksberg (Table A5) and Hillerød (Table A6).

Changes with ThinPrep technologies. After full implementation of ThinPrep LBC and reading technologies in Odense, the detection of CIN2 and the frequency of CIN treatments statistically significantly increased at 23-29 years, by 77 and $22 \%$, respectively. Among older women, the decreases in the frequency of $<\mathrm{CIN} 2$ biopsies ( $-29 \%$ at $30-44$ years and $-61 \%$ at $45-59$ years) and of false-positive tests $(-36 \%$ at $30-44$ years and $-65 \%$ at $45-59$ years) were statistically significant (Table 3 ). Correspondingly, the overall PPV increased by $51 \%$ (for $\geqslant \mathrm{CIN} 2$ ) and $41 \%$ (for $\geqslant \mathrm{CIN} 3$ ); at age $45-59$ years, the increase was particularly high, $105 \%$ for $\geqslant$ CIN2.

ThinPrep LBC implementation (comparing phase 2 with phase 1, using manual reading in both phases) was associated with a statistically significant decrease in the frequency of false-positive tests at all ages ( $-18 \%$ at $23-29$ years, $-53 \%$ at $30-44$ years, and $-76 \%$ at $45-59$ years; Table A7). The frequency of $<$ CIN2 biopsies also decreased $(-41 \%$ at $30-44$ years and $-69 \%$ at 45-59 years). There was a tendency toward a decreased detection of CIN2 and a slightly increased detection of $\geqslant \mathrm{CIN} 3$ in all three age groups, although these changes were not statistically significant. The PPV increased particularly at 30-44 years (by $83 \%$ for $\geqslant C I N 3$ ) and at $45-59$ years (by $302 \%$ for $\geqslant C I N 3$ ).

With ThinPrep Imaging System (comparing phase 3 with phase 2 , using ThinPrep LBC in both phases), the detection of CIN2 at 23-29 years increased significantly $(+135 \%)$, and detection of $\geqslant \mathrm{CIN} 3$ at $45-59$ years decreased $(-53 \%)$. Also, the frequency of false-positive tests increased, by $34 \%$ at $30-44$ years, and by $45 \%$ at 45-59 years. Consequently, the PPV decreased, by $24 \%$ (for $\geqslant \mathrm{CIN} 3$ ) at $23-29$ years, and by $63 \%$ (for $\geqslant \mathrm{CIN} 3$ ) at $45-59$ years.

\section{DISCUSSION}

General findings. In the Danish routine screening data, cytology using SurePath LBC and FocalPoint computer-assisted reading technologies (with possibly also an intervening effect of HPV triage) appeared to be more sensitive for the detection of highgrade CIN but less specific compared with manually read conventional cytology, predominantly at younger ages. ThinPrep LBC, on the other hand, decreased the sensitivity toward CIN2, but 
Table 2. Primary cytology samples and histological outcomes after 2.5-year follow-up ${ }^{\text {a }}$

\begin{tabular}{|c|c|c|c|c|c|}
\hline & Phase 1 & Phase 2 & Phase 3 & Phase 4 & Phase 5 \\
\hline Unchanged technology: Roskilde & $\begin{array}{l}\text { Baseline: } \\
\text { Conventional } \\
\text { cytology, manual } \\
\text { reading, cytology } \\
\text { triage of ASCUS } \\
(N=53979)\end{array}$ & $\begin{array}{l}\text { Conventional } \\
\text { cytology, manual } \\
\text { reading, cytology } \\
\text { triage of ASCUS } \\
(N=49856)\end{array}$ & $\begin{array}{l}\text { Conventional } \\
\text { cytology, manual } \\
\text { reading, cytology } \\
\text { triage of ASCUS } \\
(N=47300)\end{array}$ & Not relevant & Not relevant \\
\hline$\geqslant$ ASCUS & $1173(2 \%)$ & $1251(3 \%)$ & $1012(2 \%)$ & - & - \\
\hline CIN2 & $118(0.22 \%)$ & $104(0.21 \%)$ & $85(0.18 \%)$ & - & - \\
\hline$\geqslant \mathrm{CIN} 3$ & $281(0.52 \%)$ & $289(0.58 \%)$ & $271(0.57 \%)$ & - & - \\
\hline $\mathrm{CIN}$ treatments & $482(0.9 \%)$ & $491(1.0 \%)$ & $405(0.9 \%)$ & - & - \\
\hline$<\mathrm{CIN} 2$ & $471(0.87 \%)$ & $439(0.88 \%)$ & $323(0.68 \%)$ & - & - \\
\hline False positive for $\geqslant \mathrm{CIN} 2$ & $774(1.4 \%)$ & $858(1.7 \%)$ & $656(1.4 \%)$ & - & - \\
\hline False positive for $\geqslant \mathrm{CIN} 3$ & $892(1.7 \%)$ & $962(1.9 \%)$ & $741(1.6 \%)$ & - & - \\
\hline PPV for $\geqslant C I N 2$ & $34 \%$ & $31 \%$ & $35 \%$ & - & - \\
\hline $\mathrm{PPV}$ for $\geqslant \mathrm{CIN} 3$ & $24 \%$ & $23 \%$ & $27 \%$ & - & - \\
\hline $\begin{array}{l}\text { SurePath technology: Hvidovre } \\
\text { (Copenhagen) }\end{array}$ & $\begin{array}{l}\text { Baseline: } \\
\text { Conventional } \\
\text { cytology, manual } \\
\text { reading, cytology } \\
\text { triage of ASCUS } \\
(N=62644)\end{array}$ & $\begin{array}{l}\text { Conventional } \\
\text { cytology, FocalPoint } \\
\text { Slide Profiler } 50 \% \\
\text { cutoff, cytology } \\
\text { triage of ASCUS } \\
(N=59274)\end{array}$ & $\begin{array}{l}\text { SurePath LBC, } \\
\text { FocalPoint Slide } \\
\text { Profiler } 50 \% \text { cutoff, } \\
\text { cytology triage of } \\
\text { ASCUS } \\
(N=94541)\end{array}$ & $\begin{array}{l}\text { SurePath LBC, FocalPoint } \\
\text { Slide Profiler } 25 \% \text { cutoff, } \\
\text { HC2 triage of ASCUS } \\
(N=43002)\end{array}$ & $\begin{array}{c}\text { SurePath LBC, } \\
\text { FocalPoint Slide Profiler } \\
25 \% \text { cutoff + FocalPoint } \\
\text { Imaging System, HC2 } \\
\text { triage of ASCUS } \\
(N=23849)\end{array}$ \\
\hline$\geqslant$ ASCUS & 2299 (4\%) & 2307 (4\%) & $4832(5 \%)$ & $2751(6 \%)$ & $1742(7 \%)$ \\
\hline CIN2 & $230(0.37 \%)$ & $201(0.34 \%)$ & $423(0.45 \%)$ & $242(0.56 \%)$ & $162(0.68 \%)$ \\
\hline$\geqslant \mathrm{CIN} 3$ & $624(1.00 \%)$ & $547(0.92 \%)$ & $1148(1.21 \%)$ & 641 (1.49\%) & 394 (1.65\%) \\
\hline $\mathrm{CIN}$ treatments & $857(1.4 \%)$ & $828(1.4 \%)$ & 1780 (1.9\%) & $959(2.2 \%)$ & $603(2.5 \%)$ \\
\hline$<$ CIN2 & $722(1.15 \%)$ & $801(1.35 \%)$ & $1414(1.50 \%)$ & 844 (1.96\%) & $581(2.44 \%)$ \\
\hline False positive for $\geqslant \mathrm{CIN} 2$ & 1445 (2.3\%) & $1559(2.6 \%)$ & 3261 (3.4\%) & $1868(4.3 \%)$ & $1186(5.0 \%)$ \\
\hline False positive for $\geqslant \mathrm{CIN} 3$ & 1675 (2.7\%) & $1760(3.0 \%)$ & $3684(3.9 \%)$ & $2110(4.9 \%)$ & $1348(5.7 \%)$ \\
\hline PPV for $\geqslant$ CIN2 & $37 \%$ & $32 \%$ & $33 \%$ & $32 \%$ & $32 \%$ \\
\hline PPV for $\geqslant \mathrm{CIN} 3$ & $27 \%$ & $24 \%$ & $24 \%$ & $23 \%$ & $23 \%$ \\
\hline $\begin{array}{l}\text { SurePath technology: Hvidovre } \\
\text { (Frederiksberg) }\end{array}$ & $\begin{array}{l}\text { Baseline: As above } \\
\text { (excluded) }\end{array}$ & As above $(N=9385)$ & $\begin{array}{l}\text { As above } \\
(N=17634)\end{array}$ & As above $(N=7018)$ & As above $(N=4794)$ \\
\hline$\geqslant$ ASCUS & - & 361 (4\%) & $830(5 \%)$ & $420(6 \%)$ & $352(7 \%)$ \\
\hline CIN2 & - & $26(0.28 \%)$ & $77(0.44 \%)$ & $51(0.73 \%)$ & $39(0.81 \%)$ \\
\hline$\geqslant \mathrm{CIN3}$ & - & $97(1.03 \%)$ & 195 (1.11\%) & $107(1.52 \%)$ & $80(1.67 \%)$ \\
\hline $\mathrm{CIN}$ treatments & - & $134(1.4 \%)$ & $304(1.7 \%)$ & $169(2.4 \%)$ & $140(2.9 \%)$ \\
\hline$<\mathrm{CIN} 2$ & - & $113(1.20 \%)$ & $239(1.36 \%)$ & $105(1.50 \%)$ & $122(2.54 \%)$ \\
\hline False positive for $\geqslant \mathrm{CIN} 2$ & - & $238(2.5 \%)$ & $558(3.2 \%)$ & $262(3.7 \%)$ & $233(4.9 \%)$ \\
\hline False positive for $\geqslant \mathrm{CIN} 3$ & - & $264(2.8 \%)$ & $635(3.6 \%)$ & $313(4.5 \%)$ & $272(5.7 \%)$ \\
\hline PPV for $\geqslant \mathrm{CIN} 2$ & - & $34 \%$ & $33 \%$ & $38 \%$ & $34 \%$ \\
\hline PPV for $\geqslant \mathrm{CIN} 3$ & - & $27 \%$ & $23 \%$ & $25 \%$ & $23 \%$ \\
\hline SurePath technology: Hillerød & $\begin{array}{c}\text { Baseline: } \\
\text { Conventional } \\
\text { cytology, manual } \\
\text { reading, cytology } \\
\text { triage of ASCUS } \\
\text { (excluded) }\end{array}$ & $\begin{array}{l}\text { Conventional } \\
\text { cytology, FocalPoint } \\
\text { Slide Profiler } 50 \% \\
\text { cutoff, cytology } \\
\text { triage of ASCUS } \\
(N=28888)\end{array}$ & $\begin{array}{l}\text { SurePath LBC, } \\
\text { FocalPoint Slide } \\
\text { Profiler } 25 \% \text { cutoff, } \\
\text { cytology triage of } \\
\text { ASCUS } \\
\text { (N=24593) }\end{array}$ & $\begin{array}{l}\text { SurePath LBC, FocalPoint } \\
\text { Slide Profiler } 25 \% \\
\text { cutoff + FocalPoint } \\
\text { Imaging System, cytology } \\
\text { triage of ASCUS } \\
(N=18434)\end{array}$ & Not relevant \\
\hline$\geqslant$ ASCUS & - & $878(3 \%)$ & $865(4 \%)$ & $843(5 \%)$ & - \\
\hline CIN2 & - & $67(0.23 \%)$ & $71(0.29 \%)$ & $77(0.42 \%)$ & - \\
\hline$\geqslant \mathrm{CIN} 3$ & - & $151(0.52 \%)$ & $183(0.74 \%)$ & $181(0.98 \%)$ & - \\
\hline $\mathrm{CIN}$ treatments & - & 281 (1.0\%) & $291(1.2 \%)$ & $280(1.5 \%)$ & - \\
\hline$<\mathrm{CIN} 2$ & - & $318(1.10 \%)$ & $298(1.21 \%)$ & 275 (1.49\%) & - \\
\hline False positive for $\geqslant \mathrm{CIN} 2$ & - & $660(2.3 \%)$ & $611(2.5 \%)$ & $585(3.2 \%)$ & - \\
\hline False positive for $\geqslant \mathrm{CIN} 3$ & - & $727(2.5 \%)$ & $682(2.8 \%)$ & $662(3.6 \%)$ & - \\
\hline PPV for $\geqslant \mathrm{CIN} 2$ & - & $25 \%$ & $29 \%$ & $31 \%$ & - \\
\hline$P P V$ for $\geqslant C I N 3$ & - & $17 \%$ & $21 \%$ & $21 \%$ & - \\
\hline
\end{tabular}




\begin{tabular}{|c|c|c|c|c|c|}
\hline & Phase 1 & Phase 2 & Phase 3 & Phase 4 & Phase 5 \\
\hline ThinPrep technologies: Odense & $\begin{array}{l}\text { Baseline: } \\
\text { Conventional } \\
\text { cytology, manual } \\
\text { reading, cytology } \\
\text { triage of ASCUS } \\
(N=74522)\end{array}$ & $\begin{array}{l}\text { ThinPrep LBC, } \\
\text { manual reading, } \\
\text { cytology triage of } \\
\text { ASCUS ( } N=20921)\end{array}$ & $\begin{array}{l}\text { ThinPrep LBC, } \\
\text { ThinPrep Imaging } \\
\text { System, cytology } \\
\text { triage of ASCUS } \\
(N=33614)\end{array}$ & Not relevant & Not relevant \\
\hline$\geqslant$ ASCUS & $3423(5 \%)$ & $536(3 \%)$ & $1087(3 \%)$ & - & - \\
\hline CIN2 & $183(0.25 \%)$ & $31(0.15 \%)$ & $106(0.32 \%)$ & - & - \\
\hline$\geqslant \mathrm{CIN} 3$ & $557(0.75 \%)$ & $163(0.78 \%)$ & $249(0.74 \%)$ & - & - \\
\hline $\mathrm{CIN}$ treatments & $826(1.1 \%)$ & $219(1.0 \%)$ & $389(1.2 \%)$ & - & - \\
\hline$<$ CIN2 & $1507(2.02 \%)$ & $215(1.03 \%)$ & $433(1.29 \%)$ & - & - \\
\hline False positive for $\geqslant \mathrm{CIN} 2$ & $1683(3.6 \%)$ & $342(1.6 \%)$ & $732(2.2 \%)$ & - & - \\
\hline False positive for $\geqslant \mathrm{CIN} 3$ & $2866(3.8 \%)$ & $373(1.8 \%)$ & $838(2.5 \%)$ & - & - \\
\hline $\mathrm{PPV}$ for $\geqslant \mathrm{CIN} 2$ & $22 \%$ & $36 \%$ & $33 \%$ & - & - \\
\hline PPV for $\geqslant \mathrm{CIN} 3$ & $16 \%$ & $30 \%$ & $23 \%$ & - & - \\
\hline \multicolumn{6}{|c|}{ 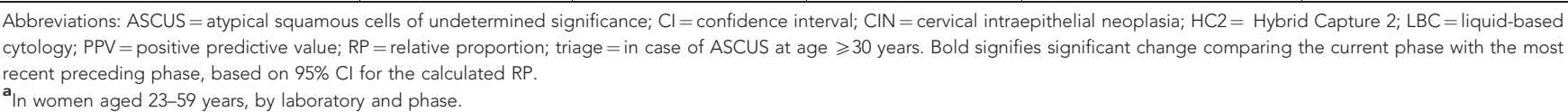 } \\
\hline
\end{tabular}

with higher specificity compared with conventional cytology, particularly at older ages. ThinPrep computer-assisted reading technologies were associated with a decrease in the specificity compared with manual reading, but generally without corresponding increases in high-grade CIN detection other than of CIN2 in young women.

Comparison with the literature. In particular, the early literature on new cytological technologies was dominated by studies in the so-called 'referral populations'. These women represented selected subgroups of the screening population (Rebolj et al, 2014a), identified as eligible after presenting with abnormal conventional cytology. Hence, unlike in our study, lesions detectable using LBC but less likely to be seen on conventional cytology would not be considered. This might be one of the reasons why an influential meta-analysis from 2008 concluded that LBC is as sensitive for detection of $\geqslant \mathrm{CIN} 2$ as conventional cytology, relative sensitivity 1.03 (95\% CI: 0.97-1.09) (Arbyn et al, 2008).

The LBC literature on primary screening has been dominated by ThinPrep studies, but those led to widely differing results. In a small French screening study $(n=1757)$, in which all women underwent colposcopy, the sensitivity of ThinPrep LBC was $66 \%$ (95\% CI: 56-75), slightly but significantly $(P<0.05)$ lower compared with that of conventional cytology, 72\% (95\% CI: 6380) (Coste et al, 2003). In that study, LBC slides were made from the material remaining after the conventional slides had been prepared. Consistent with our data, two large randomised controlled trials, from the Netherlands $(n=89784)$ and Italy ( $n=45174)$, observed the same detection of high-grade CIN with ThinPrep LBC and conventional cytology (Ronco et al, 2007; Siebers et al, 2009). However, in a smaller Swedish trial $(n=13484)$ ThinPrep LBC detected 62\% (95\% CI: 22-116) more high-grade CIN compared with conventional cytology (Strander et al, 2007). Also in a German trial comparing ThinPrep LBC with conventional cytology at $\geqslant 20$ years $(n=20935)$ (Klug et al, 2013), ThinPrep LBC detected substantially more $\geqslant$ CIN2 compared with conventional cytology, RR: 2.40 (95\% CI: 1.49-3.87). Although other factors probably also had a role, the sensitivity of conventional cytology might have differed across these studies. Reading of conventional cytology tended to rely on internal training, potentially allowing for interlaboratory variation. For patented LBC technologies, the training and certification is the manufacturer's responsibility, and the clinical outcomes thereof might be more uniform across laboratories.

A dearth of SurePath LBC studies with histological confirmation of CIN created a void in the literature, thus our findings of an increased sensitivity at younger ages could not be adequately compared. There are three major differences between ThinPrep and SurePath LBC that may have contributed to the observed variation in CIN detection. First, ThinPrep contains methanol, whereas SurePath contains formaldehyde and ethanol, leading to a different morphology presentation on the final microscopy slide. Second, SurePath cell material is first cleaned up for mucus and debris on a column. ThinPrep is processed directly out of the vial; samples are aspirated through a filter and dispensed onto the slide, which potentially leaves cell material in the filter. Finally, for a ThinPrep sample, the brush is rinsed in the liquid and afterwards discarded by the smear taker, whereas the brush head is left in SurePath until the cell material is transferred to the preprocessing column before sedimentation on the cytology slide in the laboratory. Taken together with the different vial sizes $(20 \mathrm{ml}$ for ThinPrep and $10 \mathrm{ml}$ for SurePath), this may potentially yield differences in the available cellularity (Bigras et al, 2003; Umana et al, 2013).

There have been few large evaluations of computer-assisted reading technology with a histological reference. Most notably, the large UK randomised controlled trial MAVARIC $(n=73266)$ compared ThinPrep and FocalPoint imaging-assisted reading with manual reading in predominantly primary screening samples (Kitchener et al, 2011b). Samples from some non-randomised practices and from colposcopy clinics were included to raise the number of abnormal samples. Unlike in our study, both ThinPrep and FocalPoint were inferior in detecting high-grade CIN; compared with manual reading, the relative sensitivity for $\geqslant \mathrm{CIN} 2$ was 0.92 (95\% CI: 0.87-0.98) for ThinPrep and 0.90 (95\% CI: 0.850.96) for FocalPoint. In the German trial, the addition of computer-assisted reading to LBC slightly increased the relative detection of $\geqslant$ CIN2 compared with manually read conventional cytology, from 2.40 (with ThinPrep LBC alone, see above) to 2.70 (95\% CI: 1.69-4.31; for ThinPrep LBC + computer-assisted reading). Also in two large Australian screening laboratories, ThinPrep LBC combined with Imaging missed fewer high-grade CIN compared with manually read conventional cytology (Davey et al, 2007; Halford et al, 2010). 
Table 3. Effect of full implementation of SurePath/FocalPoint or ThinPrep LBC and computer-assisted reading (last phase) ${ }^{a}$

\begin{tabular}{|c|c|c|c|}
\hline & No change (Roskilde) ${ }^{b}$ & SurePath (Hvidovre [CPH M]) & ThinPrep (Odense) ${ }^{d}$ \\
\hline Before & $\begin{array}{l}\text { Baseline: Conventional cytology, } \\
\text { manual reading, cytology triage of } \\
\text { ASCUS }\end{array}$ & $\begin{array}{l}\text { Baseline: conventional cytology, manual reading, } \\
\text { cytology triage of ASCUS }\end{array}$ & $\begin{array}{c}\text { Baseline: Conventional cytology, } \\
\text { manual reading, cytology triage of } \\
\text { ASCUS }\end{array}$ \\
\hline After & As above & $\begin{array}{c}\text { SurePath LBC, FocalPoint Slide Profiler } 25 \% \\
\text { cutoff + FocalPoint Imaging System, HC2 triage of } \\
\text { ASCUS }\end{array}$ & $\begin{array}{l}\text { ThinPrep LBC, ThinPrep Imaging } \\
\text { System, cytology triage of ASCUS }\end{array}$ \\
\hline $23-59$ years & $47300 / 53979$ & $23849 / 62644$ & $33614 / 74522$ \\
\hline$\geqslant$ ASCUS & $1012 / 1173,0.98(0.91-1.07)$ & $1742 / 2299,1.99(1.87-2.11)$ & $1087 / 3423,0.70(0.66-0.75)$ \\
\hline CIN2 & $85 / 118,0.82(0.62-1.09)$ & $162 / 230,1.85(1.51-2.26)$ & $106 / 183,1.28(1.01-1.63)$ \\
\hline$\geqslant \mathrm{CIN} 3$ & $271 / 281,1.10(0.93-1.30)$ & $394 / 624,1.66(1.46-1.88)$ & 249/557, $0.99(0.85-1.15)$ \\
\hline $\mathrm{CIN}$ treatments & $405 / 482,0.96(0.84-1.09)$ & $603 / 857,1.85(1.67-2.05)$ & $389 / 826,1.04(0.93-1.18)$ \\
\hline$<\mathrm{CIN} 2$ & $323 / 471,0.78(0.68-0.90)$ & $581 / 722,2.11(1.90-2.36)$ & $433 / 1507 ; 0.64(0.57-0.71)$ \\
\hline False positive for $\geqslant \mathrm{CIN} 2$ & $656 / 774,0.97(0.87-1.07)$ & $1186 / 1445,2.16(2.00-2.32)$ & $732 / 2683,0.60(0.56-0.66)$ \\
\hline False positive for $\geqslant \mathrm{CIN} 3$ & $741 / 892,0.95$ (0.86-1.04) & $1348 / 1675,2.11$ (1.97-2.27) & $838 / 2866,0.65(0.60-0.70)$ \\
\hline PPV for $\geqslant$ CIN2 & $35 \% / 34 \%, 1.03(0.92-1.16)$ & $32 \% / 37 \%, 0.86(0.79-0.94)$ & $33 \% / 22 \%, 1.51(1.36-1.68)$ \\
\hline $\mathrm{PPV}$ for $\geqslant \mathrm{CIN} 3$ & $27 \% / 24 \%, 1.12$ (0.97-1.29) & $23 \% / 27 \%, 0.83(0.75-0.93)$ & $23 \% / 16 \%, 1.41(1.23-1.61)$ \\
\hline $23-29$ years & $5572 / 7350$ & $8228 / 21536$ & $5310 / 14299$ \\
\hline$\geqslant$ ASCUS & $215 / 273,1.04(0.87-1.24)$ & $815 / 1020,2.09(1.91-2.28)$ & $435 / 1066,1.10(0.99-1.22)$ \\
\hline CIN2 & $22 / 38,0.76(0.45-1.29)$ & $94 / 136,1.81$ (1.39-2.35) & $61 / 93,1.77(1.28-2.44)$ \\
\hline$\geqslant \mathrm{CIN} 3$ & $71 / 73,1.28(0.93-1.78)$ & $204 / 288,1.85(1.55-2.21)$ & $103 / 250,1.11(0.88-1.39)$ \\
\hline $\mathrm{CIN}$ treatments & $103 / 133,1.02(0.79-1.32)$ & $326 / 411,2.08(1.80-2.40)$ & $167 / 373,1.21(1.01-1.44)$ \\
\hline$<\mathrm{CIN} 2$ & $49 / 91,0.71(0.50-1.00)$ & $258 / 258,2.62(2.21-3.10)$ & $142 / 372,1.03(0.85-1.24)$ \\
\hline False positive for $\geqslant \mathrm{CIN} 2$ & $122 / 162,0.99(0.79-1.25)$ & $517 / 596,2.27(2.02-2.55)$ & $271 / 723,1.01(0.88-1.16)$ \\
\hline False positive for $\geqslant \mathrm{CIN} 3$ & $144 / 200,0.95(0.77-1.17)$ & $611 / 732,2.18(1.97-2.43)$ & $332 / 816,1.10(0.97-1.24)$ \\
\hline PPV for $\geqslant$ CIN2 & $43 \% / 41 \%, 1.06(0.86-1.31)$ & $37 \% / 42 \%, 0.88(0.78-0.99)$ & $38 \% / 32 \%, 1.17(1.01-1.36)$ \\
\hline PPV for $\geqslant C I N 3$ & $33 \% / 27 \%, 1.23(0.94-1.62)$ & $25 \% / 28 \%, 0.89(0.76-1.03)$ & $24 \% / 23 \%, 1.01(0.83-1.23)$ \\
\hline 30-44 years & $21827 / 23376$ & $10081 / 24753$ & $14370 / 32819$ \\
\hline$\geqslant$ ASCUS & $544 / 548,1.06(0.95-1.20)$ & $664 / 864,1.89(1.71-2.08)$ & $472 / 1435,0.75(0.68-0.83)$ \\
\hline CIN2 & $49 / 66,0.80(0.55-1.15)$ & $62 / 84,1.81(1.31-2.51)$ & $33 / 73,1.03(0.68-1.56)$ \\
\hline$\geqslant \mathrm{CIN} 3$ & $161 / 165,1.05(0.84-1.30)$ & $176 / 273,1.58(1.31-1.91)$ & $132 / 259,1.16(0.94-1.43)$ \\
\hline $\mathrm{CIN}$ treatments & $244 / 275,0.95(0.80-1.13)$ & $252 / 360,1.72(1.47-2.02)$ & $188 / 367,1.17(0.98-1.39)$ \\
\hline$<\mathrm{CIN} 2$ & $168 / 190,0.95(0.77-1.16)$ & $238 / 258,2.27(1.90-2.70)$ & $181 / 579,0.71(0.60-0.84)$ \\
\hline False positive for $\geqslant \mathrm{CIN} 2$ & $334 / 317,1.13(0.97-1.31)$ & $426 / 507,2.06(1.82-2.34)$ & $307 / 1103,0.64(0.56-0.72)$ \\
\hline False positive for $\geqslant \mathrm{CIN} 3$ & $383 / 383,1.07(0.93-1.23)$ & $488 / 591,2.03(1.80-2.28)$ & $340 / 1176,0.66(0.59-0.74)$ \\
\hline PPV for $\geqslant C I N 2$ & $39 \% / 42 \%, 0.92(0.79-1.06)$ & $36 \% / 41 \%, 0.87(0.76-0.99)$ & $35 \% / 23 \%, 1.51(1.29-1.76)$ \\
\hline $\mathrm{PPV}$ for $\geqslant \mathrm{CIN} 3$ & $30 \% / 30 \%, 0.98$ (0.82-1.18) & $27 \% / 32 \%, 0.84(0.71-0.98)$ & $28 \% / 18 \%, 1.55(1.29-1.86)$ \\
\hline $45-59$ years & $19901 / 23253$ & $5540 / 16355$ & $13934 / 27404$ \\
\hline$\geqslant$ ASCUS & $253 / 352,0.84(0.72-0.99)$ & $263 / 415,1.87(1.61-2.18)$ & $180 / 922,0.38(0.33-0.45)$ \\
\hline CIN2 & $14 / 14,1.17(0.56-2.45)$ & $6 / 10,1.77(0.64-4.87)$ & $12 / 17,1.39(0.66-2.91)$ \\
\hline$\geqslant \mathrm{CIN} 3$ & $39 / 43,1.06(0.69-1.63)$ & $14 / 63,0.66(0.37-1.17)$ & $14 / 48,0.57(0.32-1.04)$ \\
\hline $\mathrm{CIN}$ treatments & $58 / 74,0.92(0.65-1.29)$ & $25 / 86,0.86(0.55-1.34)$ & $34 / 86,0.78(0.52-1.16)$ \\
\hline$<\mathrm{CIN} 2$ & $106 / 190,0.65(0.51-0.83)$ & $85 / 206,1.22(0.95-1.57)$ & $110 / 556,0.39(0.32-0.48)$ \\
\hline False positive for $\geqslant \mathrm{CIN} 2$ & $200 / 295,0.79(0.66-0.95)$ & $243 / 342,2.10(1.78-2.47)$ & $154 / 857,0.35(0.30-0.42)$ \\
\hline False positive for $\geqslant \mathrm{CIN} 3$ & $214 / 309,0.81(0.68-0.96)$ & $249 / 352,2.09(1.78-2.45)$ & $166 / 874,0.37(0.32-0.44)$ \\
\hline PPV for $\geqslant C I N 2$ & $21 \% / 16 \%, 1.29(0.92-1.81)$ & $8 \% / 18 \%, 0.43(0.27-0.69)$ & $14 \% / 7 \%, 2.05$ (1.34-3.14) \\
\hline PPV for $\geqslant \mathrm{CIN} 3$ & $15 \% / 12 \%, 1.26(0.84-1.89)$ & $5 \% / 15 \%, 0.35(0.20-0.61)$ & $8 \% / 5 \%, 1.49(0.84-2.65)$ \\
\hline \multicolumn{4}{|c|}{ 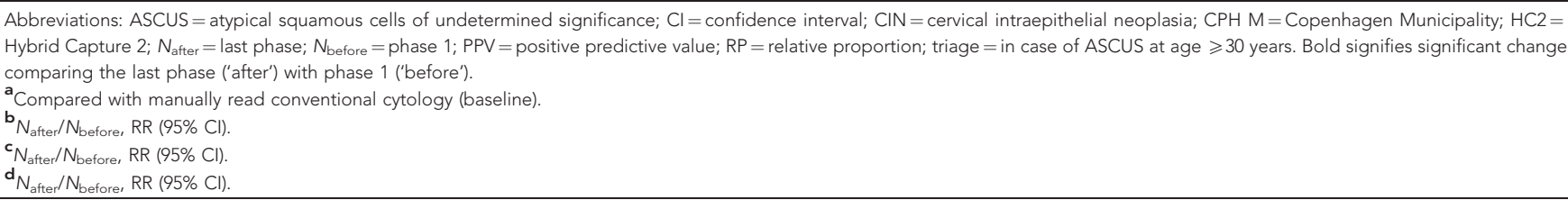 } \\
\hline
\end{tabular}



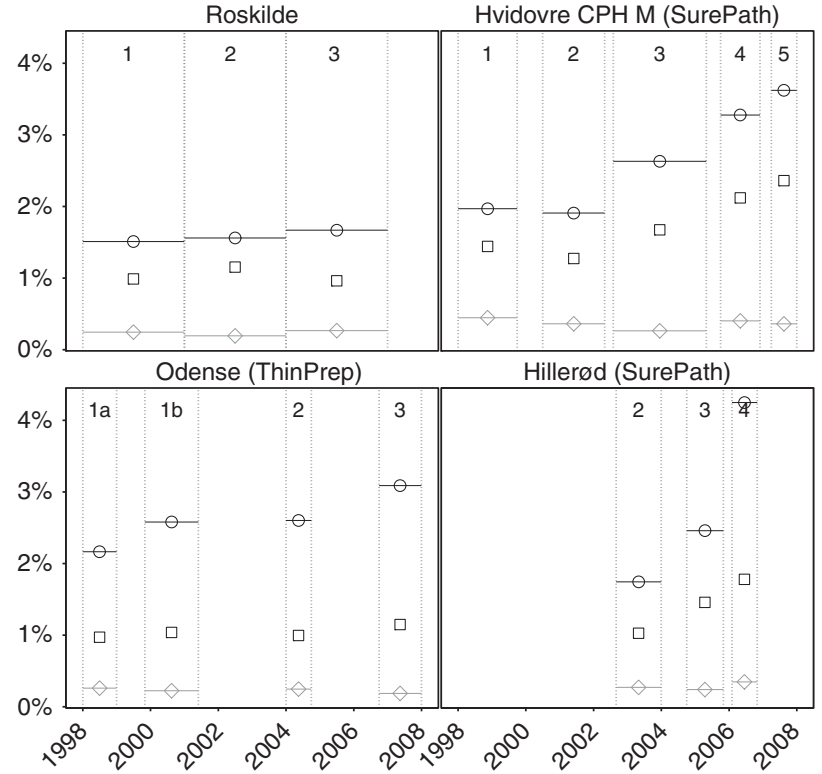

Figure 1. Frequency of histologically confirmed $\geqslant \mathrm{CIN2}$, by laboratory and phase. Roskilde: manually read conventional cytology in all phases. Hvidovre and Hillerød: SurePath/FocalPoint reading and liquid-based cytology technologies. Odense: ThinPrep reading and liquid-based cytology technologies. $\bigcirc, 23-29$ years; $\square$, 30-44 years; $\diamond, 45-59$ years. Phases as described in Table 1. CPH M, Copenhagen Municipality.
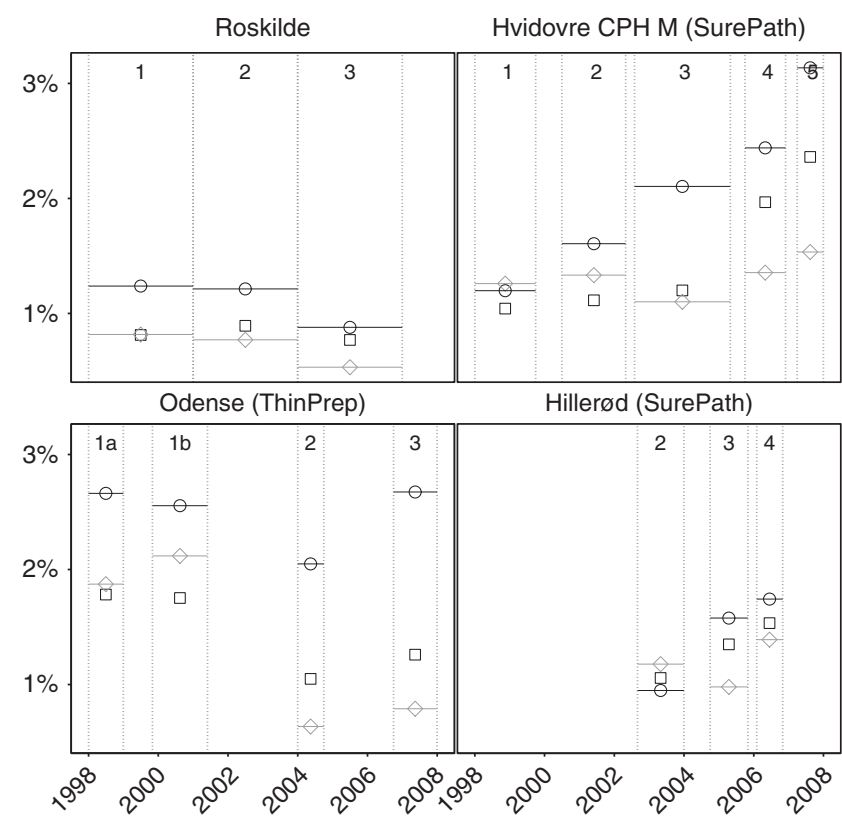

Figure 2. Frequency of histologically confirmed $<\mathrm{CIN} 2$, by laboratory and phase. Roskilde: manually read conventional cytology in all phases. Hvidovre and Hillerød: SurePath/FocalPoint reading and liquid-based cytology technologies. Odense: ThinPrep reading and liquid-based cytology technologies. $\bigcirc, 23-29$ years; $\square, 30-44$ years, and $\diamond$, 45-59 years. Phases as described in Table 1. CPH M, Copenhagen Municipality.

Strengths and weaknesses. We included routine samples from women targeted by the Danish screening programme. Abnormalities were verified through four nation-wide registers. Abnormal cytology was defined as any abnormality that would trigger follow-up,

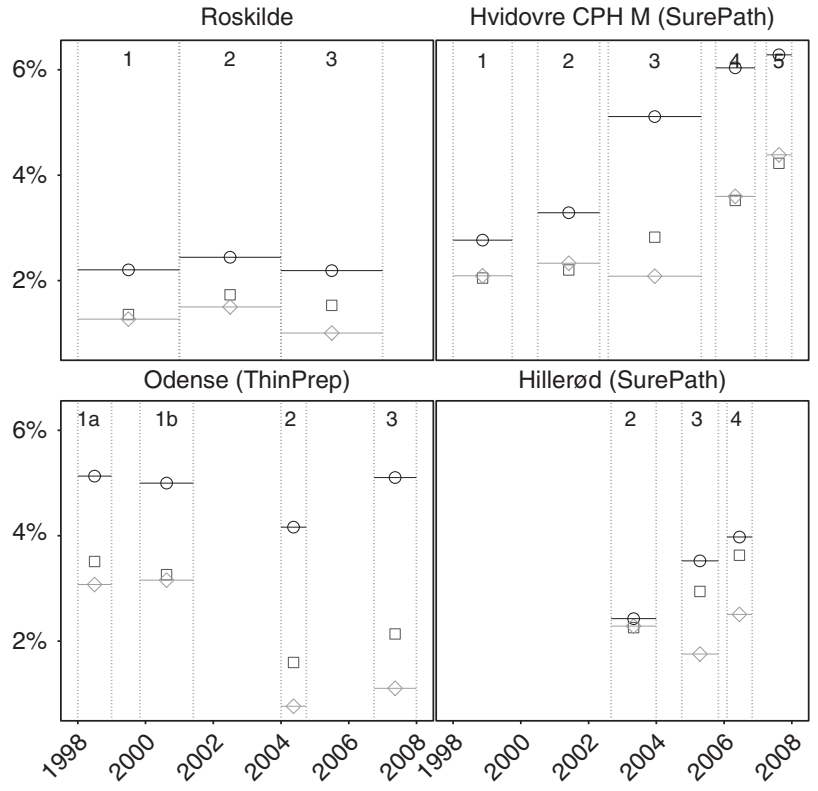

Figure 3. Frequency of false-positive tests for $\geqslant \mathrm{CIN} 2$ (samples with abnormal cytology that were not followed by a histological diagnosis of $\geqslant \mathrm{CIN} 2$ ), by laboratory and phase. Roskilde: manually read conventional cytology in all phases. Hvidovre and Hillerød: SurePath/ FocalPoint reading and liquid-based cytology technologies. Odense: ThinPrep reading and liquid-based cytology technologies. $0,23-29$ years; $\square, 30-44$ years; $\diamond, 45-59$ years. Phases as described in Table 1. $\mathrm{CPH}$, Copenhagen Municipality.

either through repeated testing or a referral for colposcopy. Histology was ascertained practically throughout the whole threeyearly screening round, and only periods with highly complete histological registration were included. Compared with other studies of routine screening, the proportion of women with histological verification of $\geqslant$ ASCUS was relatively high. We excluded all piloting and implementation periods. Although some remaining learning curve effects cannot be entirely dismissed (Kirschner et al, 2006), the outcomes of our study should be representative for a 'normal' use of the evaluated technologies.

As a limitation, it should be emphasised that ThinPrep data were based on a single laboratory. This laboratory started with a high proportion of cytological abnormalities (Rask et al, 2014), possibly signifying a relatively high sensitivity and low specificity for detecting high-grade CIN to begin with. In this laboratory, a clear advantage of ThinPrep technologies was an improvement in screening specificity.

Inferences regarding causation should be made cautiously. A competing explanation for the observed changes could be a changed risk of cervical lesions. This is, however, unlikely. First, the changes in the laboratory that continuously used manually read conventional cytology were of a substantially smaller magnitude compared with in the laboratories with changing technologies. Second, the laboratories served catchment areas in relatively close geographical proximity, and no change during the study period with a potentially differential effect on the background risk of cervical cancer could be identified.

Our study covered a 10-year period plus 2.5-year follow-up, during which the women's sociodemographic characteristics and screening histories may have changed. Ideally, these would have been adjusted for in the analysis. The age structure changed very little, and all analyses were age-stratified. Given Denmark's homogeneity, any changes in the sociodemographic factors would affect Roskilde's catchment area in a similar way as those of other laboratories. 
In our analysis, we focused on relative changes. The catchment area of Hvidovre to a higher extent included an urban population, thus absolute age-specific levels of disease detection may not have been comparable across the four laboratories. Hence, technologies were compared strictly within individual laboratories.

Clinical implications. The combination of screening and triage tests should offer the highest sensitivity for high-grade CIN and an acceptable PPV of an immediate referral to colposcopy. For reasons of cost, logistics, and women's discomfort, it is preferable to perform all screening and triage tests on the same sample. A consideration of an optimal medium for sample storage is, therefore, going to have a role also when the switch is going to be made from the present cytology-based screening with HPV triage to the imminent HPV-based screening with cytology triage. Critics have claimed that SurePath LBC medium might be unsuitable for HPV testing (Naryshkin and Austin, 2012), and none of the US Food and Drug Administration approvals for HPV assays were granted for samples stored in SurePath. Only few HPV studies evaluated SurePath samples, in particular the Danish Horizon study evaluating APTIMA, cobas, HC2, and CLART assays (Rebolj et al, 2013, 2014a, 2014b). The challenge with SurePath in HPV testing is its formaldehyde content, which induces covalent bindings between protein structures and the HPV's genetic material. These render the genetic material inaccessible to enzyme-driven amplification or detection. However, a preheating step reverses the bindings (Steinau et al, 2011). As a result, invalid HPV test results that would suggest inaccessible genetic material tend to be infrequent (Rebolj et al, 2014a). Against this background, the improved detection of high-grade CIN in SurePath samples observed in our study might be relevant also for HPV-based screening with cytology triage.

When changes are made to screening programmes, it is worth keeping in mind the more general finding from this study, in that replacing or adjusting a screening test can cause a shift in the population who tests positive, is referred for further follow-up, and finally treated. More sensitive screening methods may shift the detection toward smaller CIN lesions with a lower potential for progression (Schiffman and Rodriguez, 2008). In our study, an increased detection with LBC and/or computer-assisted reading with either brand was observed particularly at relatively young ages, when lesions less likely progress (van Oortmarssen and Habbema, 1991). To optimise screening recommendations with respect to the technology, future analyses of interval cervical cancers should determine to what extent the observed increases in the sensitivity of cytology represented overtreatment or a reduction in the burden of cervical cancer.

In conclusion, this study confirmed our earlier findings that modern cytological technologies have not been neutral with respect to the detection of cervical disease. In the Danish setting, the trends in the sensitivity and specificity depended on the type and the brand of the technology, and the age of the screened women. In essence, SurePath-based technology increased the sensitivity of cytology for high-grade cervical lesions predominantly at younger ages, whereas ThinPrep-based technology increased the specificity predominantly at older ages.

\section{ACKNOWLEDGEMENTS}

We thank Maria Franzmann, Bozena Hansen, Anni Hjortebjerg, Doris Schledermann, and Anne Wåhlin for help with retrospective mapping of technological phases by laboratory (Rask et al, 2014), and to Beth Bjerregaard for help with categorisation of SNOMED codes into Bethesda 2001 categories. According to
Danish legislation, notification to the Danish Data Inspection Agency serves as ethical approval of registry-based research projects in which no contact is made to patients, their relatives, or treating physicians. The project has notification number 2010-41-5594. JR was funded by the Danish Cancer Society (grant number: R59-A3468-12-S7). The funder had no role in study design, data collection and analysis, decision to publish, or preparation of the manuscript. The researchers worked independently of the funders.

\section{CONFLICT OF INTEREST}

$\mathrm{JR}, \mathrm{MvB}$, and BK declare no conflict of interest. $\mathrm{MR}, \mathrm{JB}, \mathrm{CR}$, and EL are undertaking a comparative study of new-generation HPV assays, involving collaboration with Roche, Genomica, Qiagen, and Hologic, and a self-sampling pilot involving collaboration with Genomica, BD, and Rovers. MR and her former employer received honoraria from Qiagen for lectures on her behalf. KR was invited by $\mathrm{BD}$ to present her work at an international conference, for which she received no honorarium. JB used to serve as a paid advisor to Roche, is a paid advisor to Genomica, and received honoraria from Hologic, Roche, Qiagen, Genomica, and BD Diagnostics for lectures. He is a principal investigator on studies funded by BD Diagnostics. CR served as an unpaid advisor to Roche. EL served as an unpaid advisor to Hologic and Norchip. Hvidovre Hospital holds a recompense agreement with Genomica on a KRAS/BRAF diagnostic system. None of the authors was compensated for their work on this project, holds stock, or received bonuses from any of the manufacturers.

\section{AUTHOR CONTRIBUTIONS}

Design of the study: MR, EL; analysis of the data: MR, JR; visual representation of the data: JR; interpretation of the results: all co-authors; drafting of the manuscript: MR, JR; critical revisions of the manuscript: all co-authors; decision to submit: all coauthors.

\section{REFERENCES}

Arbyn M, Bergeron C, Klinkhamer P, Martin-Hirsch P, Siebers AG, Bulten J (2008) Liquid compared with conventional cervical cytology: a systematic review and meta-analysis. Obstet Gynecol 111: 167-177.

Barken SS, Rebolj M, Andersen ES, Lynge E (2012) Frequency of cervical intraepithelial neoplasia treatment in a well-screened population. Int J Cancer 130: 2438-2444.

Barken SS, Rebolj M, Lynge E, Junge J, Rygaard C (2013) Outcomes in cervical screening using various cytology technologies: What's age got to do with it? Eur J Cancer Prev 22: 367-373.

Barken SS, Rebolj M, Lynge E, Junge J, Rygaard C (2014) Outcomes in cervical screening using various cytology technologies: What's age got to do with it? [erratum]. Eur J Cancer Prev 23: 147.

Bigras G, Rieder MA, Lambercy JM, Kunz B, Chatelain JP, Reymond O, Comaz D (2003) Keeping collecting device in liquid medium is mandatory to ensure optimized liquid-based cervical cytologic sampling. J Low Genit Tract Dis 7: 168-174.

Coste J, Cochand-Priollet B, de Cremoux P, Le Galès C, Cartier I, Molinié V, Labbé S, Vacher-Lavenu MC, Vielh P. French Society of Clinical Cytology Study Group (2003) Cross sectional study of conventional cervical smear, monolayer cytology, and human papillomavirus DNA testing for cervical cancer screening. BMJ 326: 733.

Davey E, d'Assuncao J, Irwig L, Macaskill P, Chan SF, Richards A, Farnsworth A (2007) Accuracy of reading liquid based cytology slides using the ThinPrep Imager compared with conventional cytology: prospective study. $B M J$ 335: 31 . 
Halford JA, Batty T, Boost T, Duhig J, Hall J, Lee C, Walker K (2010) Comparison of the sensitivity of conventional cytology and the ThinPrep Imaging System for 1,083 biopsy confirmed high-grade squamous lesions. Diagn Cytopathol 38: 318-326.

Kirschner B, Simonsen K, Junge J (2006) Comparison of conventional Papanicolaou smear and SurePath liquid-based cytology in the Copenhagen population screening programme for cervical cancer. Cytopathology 17: 187-194.

Kitchener HC, Blanks R, Cubie H, Desai M, Dunn G, Legood R, Gray A, Sadique Z, Moss S. MAVARIC Trial Study Group (2011b) MAVARIC a comparison of automation-assisted and manual cervical screening: a randomised controlled trial. Health Technol Assess 15: 1-170.

Kitchener HC, Blanks R, Dunn G, Gunn L, Desai M, Albrow R, Mather J, Rana DN, Cubie H, Moore C, Legood R, Gray A, Moss S (2011a) Automation-assisted versus manual reading of cervical cytology (MAVARIC): a randomised controlled trial. Lancet Oncol 12: 56-64.

Klug SJ, Neis KJ, Harlfinger W, Malter A, König J, Spieth S, Brinkmann-Smetanay F, Kommoss F, Weyer V, Ikenberg H (2013) A randomized trial comparing conventional cytology to liquid-based cytology and computer assistance. Int J Cancer 132: 2849-2857.

Naryshkin S, Austin RM (2012) Limitations of widely used high-risk human papillomavirus laboratory-developed testing in cervical cancer screening. Drug Healthc Patient Saf 4: 167-172.

Rask J, Lynge E, Franzmann M, Hansen B, Hjortebjerg A, Rygaard C, Schledermann D, Wåhlin A, Rebolj M (2014) Impact of technology on cytology outcome in cervical cancer screening of young and older women. Int J Cancer 134: 2168-2179.

Rebolj M, Lynge E, Ejegod D, Preisler S, Rygaard C, Bonde J (2014b) Comparison of three human papillomavirus DNA assays and one mRNA assay in women with abnormal cytology. Gynecol Oncol 135: 474-480.

Rebolj M, Njor SH, Lynge E (2012) Restriction of human papillomavirus DNA testing in primary cervical screening to women above age 30: systematic review. Eur J Cancer Prev 21: 73-81.

Rebolj M, Preisler S, Ejegod DM, Bonde J, Rygaard C, Lynge E (2013) Prevalence of human papillomavirus infection in unselected SurePath Samples using the APTIMA HPV mRNA assay. J Mol Diagn 15: 670-677.
Rebolj M, Preisler S, Ejegod DM, Rygaard C, Lynge E, Bonde J (2014a) Disagreement between human papillomavirus assays: an unexpected challenge for the choice of an assay in primary cervical screening. PLoS One 9: e86835.

Ronco G, Cuzick J, Pierotti P, Cariaggi MP, Dalla Palma P, Naldoni C, Ghiringhello B, Giorgi-Rossi P, Minucci D, Parisio F, Pojer A, Schiboni ML, Sintoni C, Zorzi M, Segnan N, Confortini M (2007) Accuracy of liquid based versus conventional cytology: overall results of new technologies for cervical cancer screening: randomised controlled trial. BMJ 335: 28.

Schiffman M, Rodriguez AC (2008) Heterogeneity in CIN3 diagnosis. Lancet Oncol 9: 404-406.

Siebers AG, Klinkhamer PJ, Grefte JM, Massuger LF, Vedder JE, Beijers-Broos A, Bulten J, Arbyn M (2009) Comparison of liquid-based cytology with conventional cytology for detection of cervical cancer precursors: a randomized controlled trial. JAMA 302: 1757-1764.

Steinau M, Patel SS, Unger ER (2011) Efficient DNA extraction for HPV genotyping in formalin-fixed, paraffin-embedded tissues. J Mol Diagn 13: $377-381$.

Strander B, Andersson-Ellstrom A, Milsom I, Radberg T, Ryd W (2007) Liquid-based cytology versus conventional Papanicolaou smear in an organized screening program: a prospective randomized study. Cancer 111: $285-291$.

Umana A, Dunsmore H, Herbert A, Jokhan A, Kubba A (2013) Are significant numbers of abnormal cells lost on the discarded ThinPrep(R) broom when used for cervical cytology? Cytopathology 24: 228-234.

van Oortmarssen GJ, Habbema JD (1991) Epidemiological evidence for age-dependent regression of pre-invasive cervical cancer. Br J Cancer 64: $559-565$.

This work is published under the standard license to publish agreement. After 12 months the work will become freely available and the license terms will switch to a Creative Commons AttributionNonCommercial-Share Alike 4.0 Unported License. 


\section{APPENDIX}

Table A1. Completeness of 2.5-year follow-up after an $\geqslant$ ASCUS primary sample ${ }^{a}$

\begin{tabular}{|c|c|c|c|c|c|}
\hline & Phase 1 & Phase 2 & Phase 3 & Phase 4 & Phase 5 \\
\hline \multicolumn{6}{|c|}{ Included samples/all primary samples } \\
\hline Roskilde & $53979 / 56769(95 \%)$ & $49856 / 51902$ (96\%) & $47300 / 48717$ (97\%) & - & - \\
\hline Hvidovre (CPH M) & $62644 / 73551(85 \%)$ & $59274 / 67311(88 \%)$ & $94541 / 105483$ (90\%) & $43002 / 47164$ (91\%) & $23849 / 25587$ (93\%) \\
\hline Hvidovre (FRB M) & - & $9385 / 10540$ (89\%) & $17643 / 19567$ (90\%) & 7018/7639 (92\%) & $4794 / 5142$ (93\%) \\
\hline Hillerød & - & $28888 / 29928$ (97\%) & $24593 / 25631$ (96\%) & $18434 / 19178(96 \%)$ & - \\
\hline Odense & $74522 / 76528(97 \%)^{\mathbf{b}}$ & $20921 / 21251(98 \%)$ & $33614 / 34066(99 \%)$ & - & - \\
\hline \multicolumn{6}{|c|}{ No follow-up/ $\geqslant$ ASCUS } \\
\hline Roskilde & 78/1173 (7\%) & $64 / 1251(5 \%)$ & $51 / 1012(5 \%)$ & - & - \\
\hline Hvidovre (CPH M) & $111 / 2299(5 \%)$ & $87 / 2307(4 \%)$ & $343 / 4832(7 \%)$ & 257/2751 (9\%) & 120/1742 (7\%) \\
\hline Hvidovre (FRB M) & - & 9/361 (2\%) & $56 / 830(7 \%)$ & 43/420 (10\%) & $23 / 352$ (7\%) \\
\hline Hillerød & - & $22 / 878(3 \%)$ & $26 / 865(3 \%)$ & $30 / 843(4 \%)$ & - \\
\hline Odense & $83 / 3423(2 \%)^{c}$ & $19 / 536(4 \%)$ & $57 / 1087(5 \%)$ & - & - \\
\hline \multicolumn{6}{|c|}{ No histology follow-up/ $\geqslant$ ASCUS } \\
\hline Roskilde & $225 / 1173(19 \%)$ & $355 / 1251(28 \%)$ & $282 / 1012(28 \%)$ & - & - \\
\hline Hvidovre (CPH M) & $612 / 2299(27 \%)$ & $671 / 2307(29 \%)$ & 1504/4832 (31\%) & $767 / 2751$ (28\%) & $485 / 1742$ (28\%) \\
\hline Hvidovre (FRB M) & - & $116 / 361$ (32\%) & $263 / 830(32 \%)$ & $114 / 420(27 \%)$ & $88 / 352$ (25\%) \\
\hline Hillerød & - & $320 / 878$ (36\%) & $287 / 865$ (33\%) & $280 / 843$ (33\%) & - \\
\hline Odense & $1093 / 3423(32 \%)^{d}$ & $108 / 536(20 \%)$ & $242 / 1087$ (22\%) & - & - \\
\hline \multicolumn{6}{|c|}{ 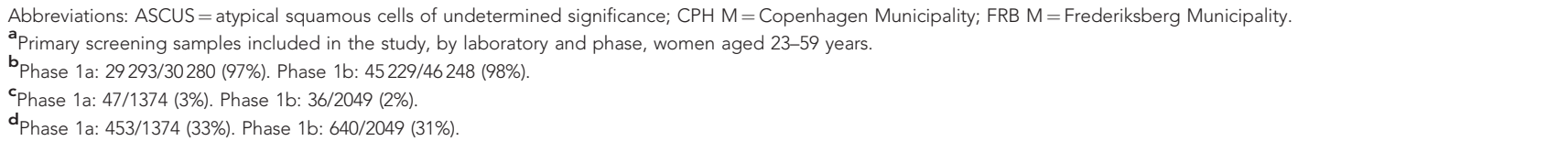 } \\
\hline
\end{tabular}

Table A2. Distribution of age groups by phase and laboratory

\begin{tabular}{|c|c|c|c|c|c|}
\hline & Phase 1 & Phase 2 & Phase 3 & Phase 4 & Phase 5 \\
\hline \multicolumn{6}{|l|}{ Roskilde } \\
\hline $23-29$ years & $7350(14 \%)$ & $6346(13 \%)$ & $5572(12 \%)$ & - & - \\
\hline 30-44 years & 23376 (43\%) & 21843 (44\%) & 21827 (46\%) & - & - \\
\hline $45-59$ years & $23253(43 \%)$ & 21667 (43\%) & 19901 (42\%) & - & - \\
\hline Total & $53797(100 \%)$ & $49856(100 \%)$ & $47300(100 \%)$ & - & - \\
\hline Mean age (s.d.) & $41.8(10.1)$ & $42.3(10.2)$ & $42.2(10.0)$ & - & - \\
\hline \multicolumn{6}{|c|}{ Hvidovre (CPH M) } \\
\hline $23-29$ years & $21536(34 \%)$ & 21537 (36\%) & 33450 (35\%) & $13733(32 \%)$ & $8228(35 \%)$ \\
\hline 30-44 years & 24753 (40\%) & $21987(37 \%)$ & 37576 (40\%) & $18348(43 \%)$ & $10081(42 \%)$ \\
\hline $45-59$ years & 16355 (26\%) & 15750 (27\%) & 23515 (25\%) & 10921 (25\%) & $5540(23 \%)$ \\
\hline Total & $62644(100 \%)$ & 59274 (100\%) & 94541 (100\%) & 43002 (100\%) & $23849(100 \%)$ \\
\hline Mean age (s.d.) & $36.4(10.4)$ & $36.4(10.7)$ & $36.3(10.6)$ & $36.7(10.4)$ & $36.1(10.4)$ \\
\hline \multicolumn{6}{|c|}{ Hvidove (FRB M) } \\
\hline $23-29$ years & - & $2413(26 \%)$ & $4949(28 \%)$ & $1909(27 \%)$ & $1238(26 \%)$ \\
\hline $30-44$ years & - & 3683 (39\%) & 7225 (41\%) & 3071 (44\%) & 2164 (45\%) \\
\hline $45-59$ years & - & 3289 (35\%) & 5460 (31\%) & $2038(29 \%)$ & $1392(29 \%)$ \\
\hline Total & - & 9385 (100\%) & 17634 (100\%) & 7018 (100\%) & $4794(100 \%)$ \\
\hline Mean age (s.d.) & - & $39.1(11.0)$ & $38.3(11.0)$ & $38.0(10.8)$ & $38.2(10.7)$ \\
\hline \multicolumn{6}{|l|}{ Hillerød } \\
\hline $23-29$ years & - & 2637 (9\%) & $2725(11 \%)$ & $1836(10 \%)$ & - \\
\hline 30-44 years & - & $13342(46 \%)$ & $11043(45 \%)$ & 8541 (46\%) & - \\
\hline $45-59$ years & - & 12909 (45\%) & 10825 (44\%) & 8057 (44\%) & - \\
\hline Total & - & $28888(100 \%)$ & $24593(100 \%)$ & 18434 (100\%) & - \\
\hline Mean age (s.d.) & - & $42.9(9.6)$ & $42.7(10.0)$ & $42.7(9.6)$ & - \\
\hline \multicolumn{6}{|l|}{ Odense } \\
\hline $23-29$ years & $14299(19 \%)$ & 3075 (15\%) & $5310(16 \%)$ & - & - \\
\hline $30-44$ years & 32819 (44\%) & 9342 (45\%) & $14370(43 \%)$ & - & - \\
\hline $45-59$ years & 27404 (37\%) & 8504 (41\%) & 13934 (41\%) & - & - \\
\hline Total & 74522 (100\%) & 20921 (100\%) & 33614 (100\%) & - & - \\
\hline Mean age (s.d.) & $40.1(10.4)$ & $41.4(10.2)$ & $41.5(10.3)$ & - & - \\
\hline
\end{tabular}


Table A3. Laboratory with manual reading of conventional cytology throughout the study period (Roskilde) ${ }^{a}$

\begin{tabular}{|c|c|c|}
\hline & Phase 2 (baseline) vs phase 1 (baseline) & Phase 3 (baseline) vs phase 2 (baseline) \\
\hline Change in the technology & None & None \\
\hline Same technology in both phases & $\begin{array}{c}\text { Conventional cytology, manual reading, } \\
\text { cytology triage of ASCUS }\end{array}$ & $\begin{array}{c}\text { Conventional cytology, manual reading, } \\
\text { cytology triage of ASCUS }\end{array}$ \\
\hline $23-59$ years & $49856 / 53979$ & $47300 / 49856$ \\
\hline$\geqslant$ ASCUS & $1251 / 1173,1.15$ (1.07-1.25) & $1012 / 1251,0.85(0.79-0.93)$ \\
\hline CIN2 & $104 / 118,0.95(0.73-1.24)$ & $85 / 104,0.86(0.65-1.15)$ \\
\hline$\geqslant \mathrm{CIN3}$ & $289 / 281,1.11(0.95-1.31)$ & $271 / 289,0.99(0.84-1.17)$ \\
\hline $\mathrm{CIN}$ treatments & $491 / 482,1.10(0.97-1.25)$ & $405 / 491,0.87(0.76-0.99)$ \\
\hline$<\mathrm{CIN} 2$ & $439 / 471,1.01(0.89-1.15)$ & $323 / 439,0.78(0.67-0.89)$ \\
\hline False positive for $\geqslant \mathrm{CIN} 2$ & $858 / 774,1.20(1.09-1.32)$ & $656 / 858,0.81(0.73-0.89)$ \\
\hline False positive for $\geqslant \mathrm{CIN} 3$ & $962 / 892,1.17(1.07-1.28)$ & $741 / 962,0.81(0.74-0.89)$ \\
\hline PPV for $\geqslant$ CIN2 & $31 \% / 34 \%, 0.92(0.82-1.04)$ & $35 \% / 31 \%, 1.12(1.00-1.26)$ \\
\hline PPV for $\geqslant C I N 3$ & $23 \% / 24 \%, 0.96(0.84-1.11)$ & $27 \% / 23 \%, 1.16(1.00-1.34)$ \\
\hline $23-29$ years & $6346 / 7350$ & $5572 / 6346$ \\
\hline$\geqslant$ ASCUS & $254 / 273,1.08(0.91-1.27)$ & $215 / 254,0.96(0.81-1.15)$ \\
\hline CIN2 & $24 / 38,0.73(0.44-1.22)$ & $22 / 24,1.04(0.59-1.86)$ \\
\hline$\geqslant \mathrm{CIN3}$ & $75 / 73,1.19(0.86-1.64)$ & $71 / 75,1.08(0.78-1.49)$ \\
\hline $\mathrm{CIN}$ treatments & $119 / 133,1.04(0.81-1.32)$ & $103 / 119,0.99(0.76-1.28)$ \\
\hline$<\mathrm{CIN} 2$ & $77 / 91,0.98(0.72-1.33)$ & $49 / 77,0.72(0.51-1.04)$ \\
\hline False positive for $\geqslant \mathrm{CIN} 2$ & $155 / 162,1.11(0.89-1.38)$ & $122 / 155,0.90(0.71-1.13)$ \\
\hline False positive for $\geqslant \mathrm{CIN} 3$ & $179 / 200,1.04(0.85-1.26)$ & $144 / 179,0.92(0.74-1.14)$ \\
\hline PPV for $\geqslant C I N 2$ & $39 \% / 41 \%, 0.96(0.78-1.18)$ & $43 \% / 39 \%, 1.11(0.89-1.38)$ \\
\hline $\mathrm{PPV}$ for $\geqslant \mathrm{CIN} 3$ & $30 \% / 27 \%, 1.10(0.84-1.45)$ & $33 \% / 30 \%, 1.12(0.85-1.46)$ \\
\hline $30-44$ years & $21843 / 23376$ & $21827 / 21843$ \\
\hline$\geqslant$ ASCUS & $630 / 548,1.23(1.10-1.38)$ & $544 / 630,0.86(0.77-0.97)$ \\
\hline CIN2 & $72 / 66,1.17(0.84-1.63)$ & $49 / 72,0.68(0.47-0.98)$ \\
\hline$\geqslant \mathrm{CIN3}$ & $180 / 165,1.17(0.95-1.44)$ & $161 / 180,0.90(0.72-1.11)$ \\
\hline $\mathrm{CIN}$ treatments & $305 / 375,1.19(1.01-1.40)$ & $244 / 305,0.80(0.68-0.95)$ \\
\hline$<\mathrm{CIN} 2$ & $195 / 190,1.10(0.90-1.34)$ & $168 / 195,0.86(0.70-1.06)$ \\
\hline False positive for $\geqslant \mathrm{CIN} 2$ & $378 / 317,1.28(1.10-1.48)$ & $334 / 378,0.88(0.76-1.02)$ \\
\hline False positive for $\geqslant \mathrm{CIN} 3$ & $450 / 383,1.26(1.10-1.44)$ & $383 / 450,0.85(0.74-0.97)$ \\
\hline PPV for $\geqslant \mathrm{CIN} 2$ & $40 \% / 42 \%, 0.95(0.83-1.09)$ & $39 \% / 40 \%, 0.97(0.84-1.11)$ \\
\hline $\mathrm{PPV}$ for $\geqslant \mathrm{CIN} 3$ & $29 \% / 30 \%, 0.95(0.79-1.13)$ & $30 \% / 29 \%, 1.04(0.87-1.24)$ \\
\hline $45-59$ years & $21667 / 23253$ & $19901 / 21667$ \\
\hline$\geqslant$ ASCUS & $367 / 352,1.12(0.97-1.29)$ & $253 / 367,0.75(0.64-0.88)$ \\
\hline CIN2 & $8 / 14,0.61(0.26-1.46)$ & $14 / 8,1.91(0.80-4.54)$ \\
\hline$\geqslant \mathrm{CIN} 3$ & $34 / 43,0.85$ (0.54-1.33) & $39 / 34,1.25(0.79-1.98)$ \\
\hline $\mathrm{CIN}$ treatments & $67 / 74,0.97(0.70-1.35)$ & $58 / 67,0.94(0.66-1.34)$ \\
\hline$<\mathrm{CIN} 2$ & $167 / 190,0.94(0.77-1.16)$ & $106 / 167,0.69(0.54-0.88)$ \\
\hline False positive for $\geqslant \mathrm{CIN} 2$ & $325 / 295,1.18(1.01-1.38)$ & $200 / 325,0.67(0.56-0.80)$ \\
\hline False positive for $\geqslant \mathrm{CIN} 3$ & $333 / 309,1.16(0.99-1.35)$ & $214 / 333,0.70(0.59-0.83)$ \\
\hline PPV for $\geqslant$ CIN2 & $11 \% / 16 \%, 0.71(0.49-1.02)$ & $21 \% / 11 \%, 1.83(1.26-2.66)$ \\
\hline PPV for $\geqslant \mathrm{CIN} 3$ & $9 \% / 12 \%, 0.76(0.50-1.16)$ & $15 \% / 9 \%, 1.66(1.08-2.56)$ \\
\hline
\end{tabular}


Table A4. Laboratory with SurePath cytological technology (Hvidovre/Copenhagen Municipality) ${ }^{\text {a }}$

\begin{tabular}{|c|c|c|c|c|}
\hline & Phase 2 vs phase 1 & Phase 3 vs phase 2 & Phase 4 vs phase 3 & Phase 5 vs phase 4 \\
\hline Change in the technology & $\begin{array}{c}\text { FocalPoint Slide Profiler 50\% } \\
\text { cutoff }\end{array}$ & SurePath LBC & $\begin{array}{c}\text { FocalPoint Slide Profiler cutoff } \\
\text { decreased to } 25 \%, \text { HC2 triage of } \\
\text { ASCUS }\end{array}$ & FocalPoint GS Imaging System \\
\hline Same technology in both phases & $\begin{array}{l}\text { Conventional cytology, } \\
\text { cytology triage of ASCUS }\end{array}$ & $\begin{array}{l}\text { FocalPoint Slide Profiler 50\% } \\
\text { cutoff, cytology triage of } \\
\text { ASCUS }\end{array}$ & SurePath LBC & $\begin{array}{c}\text { SurePath LBC, FocalPoint Slide } \\
\text { Profiler } 25 \% \text { cutoff, HC2 triage of } \\
\text { ASCUS }\end{array}$ \\
\hline $23-59$ years & $59274 / 62644$ & $94541 / 59274$ & $43002 / 94541$ & $23849 / 43002$ \\
\hline$\geqslant$ ASCUS & $2307 / 2299,1.06(1.00-1.12)$ & $4832 / 2307,1.31(1.25-1.38)$ & $2751 / 4832,1.25(1.20-1.31)$ & $1742 / 2751,1.14(1.08-1.21)$ \\
\hline CIN2 & $201 / 230,0.92(0.76-1.12)$ & $423 / 201,1.32(1.12-1.56)$ & $242 / 423,1.26(1.07-1.47)$ & $162 / 242,1.21(0.99-1.47)$ \\
\hline$\geqslant \mathrm{CIN} 3$ & $547 / 624,0.93(0.83-1.04)$ & $1148 / 547,1.32(1.19-1.46)$ & $641 / 1148,1.23(1.12-1.35)$ & $394 / 641,1.11(0.98-1.26)$ \\
\hline $\mathrm{CIN}$ treatments & $828 / 857,1.02(0.93-1.12)$ & $1780 / 828,1.35(1.24-1.46)$ & $959 / 1780,1.18(1.10-1.28)$ & $603 / 959,1.13(1.03-1.25)$ \\
\hline$<\mathrm{CIN} 2$ & $801 / 722,1.17(1.06-1.30)$ & $1414 / 801,1.11(1.02-1.21)$ & $844 / 1414,1.31$ (1.21-1.43) & $581 / 844,1.24$ (1.12-1.38) \\
\hline False positive for $\geqslant \mathrm{CIN} 2$ & $1559 / 1445,1.14$ (1.06-1.22) & $3261 / 1559,1.31$ (1.24-1.39) & $1868 / 3261,1.26(1.19-1.33)$ & $1186 / 1868,1.14(1.07-1.23)$ \\
\hline False positive for $\geqslant \mathrm{CIN} 3$ & $1760 / 1675,1.11(1.04-1.19)$ & $3684 / 1760,1.31(1.24-1.39)$ & $2110 / 3684,1.26(1.20-1.33)$ & $1348 / 2110,1.15(1.08-1.23)$ \\
\hline PPV for $\geqslant \mathrm{CIN} 2$ & $32 \% / 37 \%, 0.87(0.81-0.94)$ & $33 \% / 32 \%, 1.00(0.93-1.08)$ & $32 \% / 33 \%, 0.99(0.92-1.06)$ & $32 \% / 32 \%, 0.99(0.91-1.09)$ \\
\hline $\mathrm{PPV}$ for $\geqslant \mathrm{CIN} 3$ & $24 \% / 27 \%, 0.87(0.79-0.96)$ & $24 \% / 24 \%, 1.00(0.92-1.10)$ & $23 \% / 24 \%, 0.98(0.90-1.07)$ & $23 \% / 23 \%, 0.97(0.87-1.08)$ \\
\hline 23-29 years & $21537 / 21536$ & $33450 / 21537$ & $13733 / 33450$ & $8228 / 13733$ \\
\hline$\geqslant$ ASCUS & $1119 / 1020,1.10(1.01-1.19)$ & $2590 / 1119,1.49(1.39-1.60)$ & $1279 / 2590,1.20(1.13-1.28)$ & $815 / 1279,1.06(0.98-1.16)$ \\
\hline CIN2 & $120 / 136,0.88(0.69-1.13)$ & $251 / 120,1.35(1.08-1.67)$ & $134 / 251,1.30(1.06-1.60)$ & $94 / 134,1.17(0.90-1.52)$ \\
\hline$\geqslant \mathrm{CIN} 3$ & $291 / 288,1.01(0.86-1.19)$ & $629 / 291,1.39(1.21-1.60)$ & $316 / 629,1.22(1.07-1.40)$ & $204 / 316,1.08(0.91-1.28)$ \\
\hline $\mathrm{CIN}$ treatments & $449 / 411,1.09(0.96-1.25)$ & $996 / 449,1.43(1.28-1.59)$ & $476 / 996,1.16(1.05-1.30)$ & $326 / 476,1.14(1.00-1.31)$ \\
\hline$<\mathrm{CIN} 2$ & $346 / 258,1.34(1.14-1.57)$ & $704 / 346,1.31$ (1.15-1.49) & $335 / 704,1.16(1.02-1.32)$ & $258 / 335,1.29(1.10-1.51)$ \\
\hline False positive for $\geqslant \mathrm{CIN} 2$ & $708 / 596,1.19(1.07-1.32)$ & $1710 / 708,1.56(1.43-1.69)$ & $829 / 1710,1.18(1.09-1.28)$ & $517 / 829,1.04(0.94-1.16)$ \\
\hline False positive for $\geqslant \mathrm{CIN} 3$ & $828 / 732,1.13(1.03-1.25)$ & $1961 / 828,1.52(1.41-1.65)$ & $963 / 1961,1.20(1.11-1.29)$ & $611 / 963,1.06(0.96-1.17)$ \\
\hline PPV for $\geqslant C I N 2$ & $37 \% / 42 \%, 0.88(0.79-0.98)$ & $34 \% / 37 \%, 0.93(0.84-1.02)$ & $35 \% / 34 \%, 1.04(0.94-1.14)$ & $37 \% / 35 \%, 1.04(0.92-1.17)$ \\
\hline $\mathrm{PPV}$ for $\geqslant \mathrm{CIN} 3$ & $26 \% / 28 \%, 0.92(0.80-1.06)$ & $24 \% / 26 \%, 0.93(0.83-1.05)$ & $25 \% / 24 \%, 1.02(0.90-1.14)$ & $25 \% / 25 \%, 1.01(0.87-1.18)$ \\
\hline $30-44$ years & $21987 / 24753$ & $37576 / 21987$ & $18348 / 37576$ & $10081 / 18348$ \\
\hline$\geqslant$ ASCUS & $764 / 864,1.00(0.90-1.10)$ & $1690 / 764,1.29(1.19-1.41)$ & $1035 / 1690,1.25(1.16-1.35)$ & $664 / 1035,1.17(1.06-1.28)$ \\
\hline CIN2 & $63 / 84,0.84(0.61-1.17)$ & $154 / 63,1.43(1.07-1.92)$ & $98 / 154,1.30(1.01-1.68)$ & $62 / 98,1.15(0.84-1.58)$ \\
\hline$\geqslant \mathrm{CIN} 3$ & $217 / 273,0.89(0.75-1.07)$ & $475 / 217,1.28(1.09-1.50)$ & $291 / 475,1.25(1.09-1.45)$ & $176 / 291,1.10(0.91-1.33)$ \\
\hline $\mathrm{CIN}$ treatments & $308 / 360,0.96(0.83-1.12)$ & $702 / 308,1.33(1.17-1.52)$ & $430 / 702,1.25(1.11-1.41)$ & $252 / 430,1.07(0.91-1.24)$ \\
\hline$<\mathrm{CIN} 2$ & $245 / 258,1.07(0.90-1.27)$ & $451 / 245,1.08(0.92-1.26)$ & $361 / 451,1.64$ (1.43-1.88) & $238 / 361,1.20(1.02-1.41)$ \\
\hline False positive for $\geqslant \mathrm{CIN} 2$ & $484 / 507,1.07(0.95-1.22)$ & $1061 / 484,1.28(1.15-1.43)$ & $646 / 1061,1.25(1.13-1.37)$ & $426 / 646,1.20(1.06-1.35)$ \\
\hline False positive for $\geqslant \mathrm{CIN} 3$ & $547 / 591,1.04(0.93-1.17)$ & $1215 / 547,1.30(1.18-1.44)$ & $744 / 1215,1.25(1.15-1.37)$ & $488 / 744,1.19(1.07-1.33)$ \\
\hline PPV for $\geqslant$ CIN2 & $37 \% / 41 \%, 0.89(0.78-1.00)$ & $37 \% / 37 \%, 1.02(0.91-1.14)$ & $38 \% / 37 \%, 1.01(0.91-1.12)$ & $36 \% / 38 \%, 0.95(0.84-1.08)$ \\
\hline $\mathrm{PPV}$ for $\geqslant \mathrm{CIN} 3$ & $28 \% / 32 \%, 0.90(0.77-1.04)$ & $28 \% / 28 \%, 0.99(0.86-1.13)$ & $28 \% / 28 \%, 1.00(0.88-1.13)$ & $27 \% / 28 \%, 0.94(0.80-1.11)$ \\
\hline $45-59$ years & $15750 / 16355$ & $23515 / 15750$ & $10921 / 23515$ & $5540 / 10921$ \\
\hline$\geqslant$ ASCUS & $424 / 415,1.06(0.93-1.21)$ & $552 / 424,0.87(0.77-0.99)$ & $437 / 552,1.70(1.51-1.93)$ & $263 / 437,1.19(1.02-1.38)$ \\
\hline CIN2 & $18 / 10,1.87(0.86-4.05)$ & $18 / 18,0.67(0.35-1.29)$ & $10 / 18,1.20(0.55-2.59)$ & $6 / 10,1.18(0.43-3.25)$ \\
\hline$\geqslant \mathrm{CIN} 3$ & $39 / 63,0.64(0.43-0.96)$ & $44 / 39,0.76(0.49-1.16)$ & $34 / 44,1.66(1.06-2.60)$ & $14 / 34,0.81(0.44-1.51)$ \\
\hline $\mathrm{CIN}$ treatments & $71 / 86,0.86(0.63-1.17)$ & $82 / 71,0.77(0.56-1.06)$ & $53 / 82,1.39(0.99-1.96)$ & $25 / 53,0.93(0.58-1.49)$ \\
\hline$<\mathrm{CIN} 2$ & $210 / 206,1.06(0.87-1.28)$ & $259 / 210,0.83(0.69-0.99)$ & $148 / 259,1.23(1.01-1.50)$ & $85 / 148,1.13(0.87-1.48)$ \\
\hline False positive for $\geqslant \mathrm{CIN} 2$ & $367 / 342,1.11(0.96-1.29)$ & $490 / 367,0.89(0.78-1.02)$ & $393 / 490,1.73(1.52-1.97)$ & $243 / 393,1.22(1.04-1.43)$ \\
\hline False positive for $\geqslant \mathrm{CIN} 3$ & $385 / 352,1.14(0.98-1.31)$ & $508 / 385,0.88(0.78-1.01)$ & $403 / 508,1.71(1.50-1.94)$ & $249 / 403,1.22(1.04-1.42)$ \\
\hline PPV for $\geqslant C I N 2$ & $13 \% / 18 \%, 0.76(0.56-1.05)$ & $11 \% / 13 \%, 0.84(0.60-1.17)$ & $10 \% / 11 \%, 0.90(0.62-1.29)$ & $8 \% / 10 \%, 0.76(0.46-1.25)$ \\
\hline PPV for $\geqslant$ CIN3 & $9 \% / 15 \%, 0.61(0.42-0.88)$ & $8 \% / 9 \%, 0.87(0.57-1.31)$ & $8 \% / 8 \%, 0.98(0.64-1.50)$ & $5 \% / 8 \%, 0.68(0.37-1.25)$ \\
\hline
\end{tabular}


Table A5. Laboratory with SurePath cytological technology (Hvidovre/Frederiksberg Municipality) ${ }^{a}$

\begin{tabular}{|c|c|c|c|}
\hline & Phase 3 vs phase 2 & Phase 4 vs phase 3 & Phase 5 vs phase 4 \\
\hline Change in the technology & SurePath LBC & $\begin{array}{l}\text { FocalPoint Slide Profiler cutoff decreased } \\
\text { to } 25 \%, \mathrm{HC} 2 \text { triage of ASCUS }\end{array}$ & FocalPoint GS Imaging System \\
\hline Same technology in both phases & $\begin{array}{l}\text { FocalPoint Slide Profiler } 50 \% \\
\text { cutoff, cytology triage of ASCUS }\end{array}$ & SurePath LBC & $\begin{array}{c}\text { SurePath LBC, FocalPoint Slide Profiler } \\
25 \% \text { cutoff, HC2 triage of ASCUS }\end{array}$ \\
\hline 23-59 years & $17634 / 9385$ & $7018 / 17634$ & $4794 / 7018$ \\
\hline$\geqslant$ ASCUS & $830 / 361,1.22(1.08-1.38)$ & $420 / 830,1.27(1.13-1.43)$ & $352 / 420,1.23(1.07-1.41)$ \\
\hline CIN2 & $77 / 26,1.58(1.01-2.46)$ & $51 / 77,1.66(1.17-2.37)$ & $39 / 51,1.12(0.74-1.70)$ \\
\hline$\geqslant \mathrm{CIN} 3$ & $195 / 97,1.07(0.84-1.36)$ & $107 / 195,1.38(1.09-1.74)$ & $80 / 107,1.09(0.82-1.46)$ \\
\hline $\mathrm{CIN}$ treatments & $304 / 134,1.21(0.99-1.48)$ & $169 / 304,1.40(1.16-1.68)$ & $140 / 169,1.21(0.97-1.51)$ \\
\hline$<\mathrm{CIN} 2$ & $239 / 113,1.13(0.90-1.41)$ & $105 / 239,1.10(0.88-1.39)$ & $122 / 105,1.70(1.31-2.20)$ \\
\hline False positive for $\geqslant \mathrm{CIN} 2$ & $558 / 238,1.25(1.07-1.45)$ & $262 / 558,1.18(1.02-1.36)$ & $233 / 262,1.30(1.10-1.55)$ \\
\hline False positive for $\geqslant \mathrm{CIN} 3$ & $635 / 264,1.28(1.11-1.47)$ & $313 / 635,1.24(1.08-1.41)$ & $272 / 313,1.27(1.09-1.49)$ \\
\hline PPV for $\geqslant C I N 2$ & $33 \% / 34 \%, 0.96(0.81-1.14)$ & $38 \% / 33 \%, 1.15(0.98-1.34)$ & $34 \% / 38 \%, 0.90(0.74-1.09)$ \\
\hline PPV for CIN3 & $23 \% / 27 \%, 0.87(0.71-1.08)$ & $25 \% / 23 \%, 1.08(0.88-1.33)$ & $23 \% / 25 \%, 0.89(0.69-1.15)$ \\
\hline $23-29$ years & $4949 / 2413$ & $1909 / 4949$ & $1238 / 1909$ \\
\hline$\geqslant$ ASCUS & $367 / 133,1.35(1.11-1.63)$ & $174 / 367,1.23(1.03-1.46)$ & $135 / 174,1.20(0.97-1.48)$ \\
\hline CIN2 & $45 / 19,1.15(0.68-1.97)$ & $21 / 45,1.21(0.72-2.03)$ & $24 / 21,1.76(0.99-3.15)$ \\
\hline$\geqslant \mathrm{CIN} 3$ & $97 / 36,1.31(0.90-1.92)$ & $56 / 97,1.50(1.08-2.07)$ & $37 / 56,1.02(0.68-1.53)$ \\
\hline $\mathrm{CIN}$ treatments & $156 / 55,1.38(1.02-1.87)$ & $81 / 156,1.35$ (1.03-1.75) & $66 / 81,1.26(0.92-1.73)$ \\
\hline$<\mathrm{CIN} 2$ & $92 / 30,1.50(0.99-2.25)$ & $34 / 92,0.96(0.65-1.41)$ & $38 / 34,1.72(1.09-2.72)$ \\
\hline False positive for $\geqslant \mathrm{CIN} 2$ & $225 / 78,1.41$ (1.09-1.81) & $97 / 225,1.12(0.89-1.41)$ & $74 / 97,1.18(0.88-1.58)$ \\
\hline False positive for $\geqslant \mathrm{CIN} 3$ & $270 / 97,1.36(1.08-1.70)$ & $118 / 270,1.13(0.92-1.40)$ & $98 / 118,1.28(0.99-1.66)$ \\
\hline PPV for $\geqslant$ CIN2 & $39 \% / 41 \%, 0.94(0.74-1.19)$ & $44 \% / 39 \%, 1.14(0.93-1.41)$ & $45 \% / 44 \%, 1.02(0.80-1.31)$ \\
\hline PPV for CIN3 & $26 \% / 27 \%, 0.98(0.70-1.35)$ & $32 \% / 26 \%, 1.22(0.92-1.60)$ & $27 \% / 32 \%, 0.85(0.60-1.21)$ \\
\hline $30-44$ years & $7225 / 3683$ & $3071 / 7225$ & $2164 / 3071$ \\
\hline$\geqslant$ ASCUS & $334 / 136,1.25(1.03-1.52)$ & $176 / 334,1.24(1.04-1.48)$ & $151 / 176,1.22(0.99-1.50)$ \\
\hline CIN2 & $31 / 5,3.16(1.23-8.12)$ & $28 / 31,2.12(1.28-3.54)$ & $13 / 28,0.66(0.34-1.27)$ \\
\hline$\geqslant \mathrm{CIN} 3$ & $82 / 44,0.95(0.66-1.37)$ & $50 / 82,1.43(1.01-2.03)$ & $42 / 50,1.19(0.79-1.79)$ \\
\hline $\mathrm{CIN}$ treatments & $129 / 55,1.20(0.87-1.64)$ & $85 / 129,1.55$ (1.18-2.03) & $67 / 85,1.12(0.82-1.53)$ \\
\hline$<\mathrm{CIN} 2$ & $94 / 42,1.14(0.79-1.64)$ & $49 / 94,1.23(0.87-1.73)$ & $60 / 49,1.74(1.20-2.52)$ \\
\hline False positive for $\geqslant \mathrm{CIN} 2$ & $221 / 87,1.29(1.01-1.65)$ & $98 / 221,1.04(0.83-1.32)$ & $96 / 98,1.39(1.05-1.83)$ \\
\hline False positive for $\geqslant \mathrm{CIN} 3$ & $252 / 92,1.40(1.10-1.77)$ & $126 / 252,1.18(0.95-1.45)$ & $109 / 126,1.23(0.96-1.58)$ \\
\hline PPV for $\geqslant C I N 2$ & $34 \% / 36 \%, 0.94(0.72-1.23)$ & $44 \% / 34 \%, 1.31$ (1.05-1.64) & $36 \% / 44 \%, 0.82(0.63-1.07)$ \\
\hline PPV for CIN3 & $25 \% / 32 \%, 0.76(0.56-1.03)$ & $28 \% / 25 \%, 1.16(0.86-1.56)$ & $28 \% / 28 \%, 0.98(0.69-1.39)$ \\
\hline $45-59$ years & $5460 / 3289$ & $2038 / 5460$ & $1392 / 2038$ \\
\hline$\geqslant$ ASCUS & $129 / 92,0.84(0.65-1.10)$ & $70 / 129,1.45$ (1.09-1.94) & $66 / 70,1.38(0.99-1.92)$ \\
\hline CIN2 & $1 / 2,0.30(0.03-3.32)$ & $2 / 1,5.36(0.49-59.06)$ & $2 / 2,1.46(0.21-10.38)$ \\
\hline$\geqslant \mathrm{CIN} 3$ & $16 / 17,0.57(0.29-1.12)$ & $1 / 16,0.17(0.02-1.26)$ & $1 / 1,1.46(0.09-23.39)$ \\
\hline $\mathrm{CIN}$ treatments & $19 / 24,0.48(0.26-0.87)$ & $3 / 19,0.42(0.13-1.43)$ & $7 / 3,3.42(0.88-13.19)$ \\
\hline$<$ CIN2 & $53 / 41,0.78(0.52-1.17)$ & $22 / 53,1.11(0.68-1.82)$ & $24 / 22,1.60(0.90-2.84)$ \\
\hline False positive for $\geqslant \mathrm{CIN} 2$ & $112 / 73,0.92(0.69-1.24)$ & $67 / 112,1.60(1.19-2.16)$ & $63 / 67,1.38(0.98-1.93)$ \\
\hline False positive for $\geqslant \mathrm{CIN} 3$ & $113 / 75,0.91(0.68-1.21)$ & $69 / 113,1.64(1.22-2.20)$ & $65 / 69,1.38(0.99-1.92)$ \\
\hline $\mathrm{PPV}$ for $\geqslant \mathrm{CIN} 2$ & $13 \% / 21 \%, 0.64(0.35-1.16)$ & $4 \% / 13 \%, 0.33$ (0.10-1.07) & $5 \% / 4 \%, 1.06(0.22-5.07)$ \\
\hline PPV for CIN3 & $12 \% / 18 \%, 0.67(0.36-1.26)$ & $1 \% / 12 \%, 0.12(0.02-0.85)$ & $2 \% / 1 \%, 1.06(0.07-16.61)$ \\
\hline
\end{tabular}


Table A6. Laboratory with SurePath cytological technology (Hillerød)

\begin{tabular}{|c|c|c|}
\hline & Phase 3 vs phase 2 & Phase 4 vs phase 3 \\
\hline Change in the technology & $\begin{array}{c}\text { SurePath LBC, FocalPoint Slide Profiler cutoff } \\
\text { decreased to } 25 \%\end{array}$ & FocalPoint GS Imaging System \\
\hline Same technology in both phases & Cytology triage of ASCUS & $\begin{array}{c}\text { SurePath LBC, Focal Point Slide Profiler 25\% cutoff, cytology } \\
\text { triage of ASCUS }\end{array}$ \\
\hline 23-59 years & $24593 / 28888$ & $18434 / 24593$ \\
\hline$\geqslant$ ASCUS & $865 / 878,1.16(1.06-1.27)$ & $843 / 865,1.30(1.18-1.43)$ \\
\hline CIN2 & $71 / 67,1.24(0.89-1.74)$ & $77 / 71,1.45(1.05-2.00)$ \\
\hline$\geqslant \mathrm{CIN} 3$ & $183 / 151,1.42(1.15-1.76)$ & $181 / 183,1.32(1.08-1.62)$ \\
\hline $\mathrm{CIN}$ treatments & $291 / 281,1.22(1.03-1.43)$ & $280 / 291,1.28(1.09-1.51)$ \\
\hline$<\mathrm{CIN} 2$ & $298 / 318,1.10(0.94-1.29)$ & $275 / 298,1.23(1.05-1.45)$ \\
\hline False positive for $\geqslant \mathrm{CIN} 2$ & $611 / 660,1.09(0.98-1.21)$ & $585 / 611,1.28(1.14-1.43)$ \\
\hline False positive for $\geqslant \mathrm{CIN} 3$ & $682 / 727,1.10(0.99-1.22)$ & $662 / 682,1.29(1.17-1.44)$ \\
\hline PPV for $\geqslant \mathrm{CIN} 2$ & $29 \% / 25 \%, 1.18(1.01-1.38)$ & $31 \% / 29 \%, 1.04(0.90-1.20)$ \\
\hline PPV for $\geqslant C I N 3$ & $21 \% / 17 \%, 1.23(1.01-1.49)$ & $21 \% / 21 \%, 1.01$ (0.85-1.22) \\
\hline 23-29 years & $2725 / 2637$ & $1836 / 2725$ \\
\hline$\geqslant$ ASCUS & $163 / 110,1.43(1.13-1.82)$ & $151 / 163,1.37(1.11-1.70)$ \\
\hline CIN2 & $18 / 15,1.16(0.59-2.30)$ & $27 / 18,2.23(1.23-4.03)$ \\
\hline$\geqslant \mathrm{CIN} 3$ & 49/31, $1.53(0.98-2.39)$ & $51 / 49,1.54(1.05-2.28)$ \\
\hline $\mathrm{CIN}$ treatments & $71 / 52,1.32(0.93-1.88)$ & $80 / 71,1.67(1.22-2.29)$ \\
\hline$<\mathrm{CIN} 2$ & $43 / 25,1.66(1.02-2.72)$ & $32 / 43,1.10(0.70-1.74)$ \\
\hline False positive for $\geqslant \mathrm{CIN} 2$ & $96 / 64,1.45$ (1.06-1.98) & $73 / 96,1.13(0.84-1.52)$ \\
\hline False positive for $\geqslant \mathrm{CIN} 3$ & $114 / 79,1.40(1.05-1.85)$ & $100 / 114,1.30(1.00-1.69)$ \\
\hline PPV for $\geqslant C I N 2$ & $41 \% / 42 \%, 0.98$ (0.74-1.31) & $52 \% / 41 \%, 1.26(0.99-1.60)$ \\
\hline PPV for $\geqslant C I N 3$ & $30 \% / 28 \%, 1.07$ (0.73-1.56) & $34 \% / 30 \%, 1.12(0.81-1.55)$ \\
\hline 30-44 years & $11043 / 13342$ & $8541 / 11043$ \\
\hline$\geqslant$ ASCUS & $486 / 438,1.34(1.18-1.52)$ & $462 / 486,1.23(1.09-1.39)$ \\
\hline CIN2 & $42 / 41,1.24(0.81-1.90)$ & $42 / 42,1.29(0.84-1.98)$ \\
\hline$\geqslant \mathrm{CIN} 3$ & $119 / 96,1.50(1.15-1.96)$ & $110 / 119,1.20(0.92-1.55)$ \\
\hline CIN treatments & $183 / 166,1.33$ (1.08-1.64) & $163 / 183,1.15(0.93-1.42)$ \\
\hline$<\mathrm{CIN} 2$ & $149 / 141,1.28(1.02-1.61)$ & $131 / 149,1.14(0.90-1.44)$ \\
\hline False positive for $\geqslant \mathrm{CIN} 2$ & $325 / 301,1.30(1.12-1.52)$ & $310 / 325,1.23(1.06-1.44)$ \\
\hline False positive for $\geqslant \mathrm{CIN} 3$ & $367 / 342,1.30(1.12-1.50)$ & $352 / 367,1.24(1.07-1.43)$ \\
\hline PPV for $\geqslant C I N 2$ & $33 \% / 31 \%, 1.06(0.88-1.28)$ & $33 \% / 33 \%, 0.99(0.83-1.19)$ \\
\hline PPV for $\geqslant C I N 3$ & $24 \% / 22 \%, 1.12(0.88-1.41)$ & $24 \% / 24 \%, 0.97(0.78-1.22)$ \\
\hline $45-59$ years & $10825 / 12909$ & $8057 / 10825$ \\
\hline$\geqslant$ ASCUS & $216 / 330,0.78(0.66-0.92)$ & $230 / 216,1.43$ (1.19-1.72) \\
\hline CIN2 & $11 / 11,1.19(0.52-2.75)$ & $8 / 11,0.98(0.39-2.43)$ \\
\hline$\geqslant \mathrm{CIN} 3$ & $15 / 24,0.75(0.39-1.42)$ & $20 / 15,1.79(0.92-3.50)$ \\
\hline $\mathrm{CIN}$ treatments & $37 / 63,0.70(0.47-1.05)$ & $37 / 37,1.34(0.85-2.12)$ \\
\hline$<\mathrm{CIN} 2$ & $106 / 152,0.83(0.65-1.06)$ & $112 / 106,1.42(1.09-1.85)$ \\
\hline False positive for $\geqslant \mathrm{CIN} 2$ & $190 / 295,0.77(0.64-0.92)$ & $202 / 190,1.43(1.17-1.74)$ \\
\hline False positive for $\geqslant \mathrm{CIN} 3$ & $201 / 306,0.78(0.66-0.93)$ & $210 / 201,1.40(1.16-1.70)$ \\
\hline PPV for $\geqslant C I N 2$ & $12 \% / 11 \%, 1.13(0.70-1.83)$ & $12 \% / 12 \%, 1.01(0.61-1.67)$ \\
\hline $\mathrm{PPV}$ for $\geqslant \mathrm{CIN} 3$ & $7 \% / 7 \%, 0.95(0.51-1.78)$ & $9 \% / 7 \% .1 .25(0.66-2.38)$ \\
\hline
\end{tabular}


Table A7. Laboratory with ThinPrep cytological technology (Odense)

\begin{tabular}{|c|c|c|}
\hline & Phase 2 vs phase 1 & Phase 3 vs phase 2 \\
\hline Change in the technology & ThinPrep LBC & ThinPrep Imaging System \\
\hline Same technology in both phases & Manual reading, cytology triage of ASCUS & ThinPrep LBC, cytology triage of ASCUS \\
\hline $23-59$ years & $20921 / 74522$ & $33614 / 20921$ \\
\hline$\geqslant$ ASCUS & $536 / 3423,0.56(0.51-0.61)$ & $1087 / 536,1.26(1.14-1.40)$ \\
\hline CIN2 & $31 / 183,0.60(0.41-0.88)$ & $106 / 31,2.13(1.43-3.17)$ \\
\hline$\geqslant \mathrm{CIN} 3$ & $163 / 557,1.04(0.88-1.24)$ & $249 / 163,0.95(0.78-1.16)$ \\
\hline $\mathrm{CIN}$ treatments & $219 / 826,0.94(0.81-1.10)$ & $389 / 219,1.11(0.94-1.30)$ \\
\hline$<\mathrm{CIN} 2$ & $215 / 1507,0.51(0.44-0.59)$ & $433 / 215,1.25(1.07-1.47)$ \\
\hline False positive for $\geqslant \mathrm{CIN} 2$ & $342 / 2683,0.45(0.41-0.51)$ & $732 / 342,1.33(1.17-1.51)$ \\
\hline False positive for $\geqslant \mathrm{CIN} 3$ & $373 / 2866,0.46(0.42-0.52)$ & $838 / 373,1.40(1.24-1.58)$ \\
\hline PPV for $\geqslant C I N 2$ & $36 \% / 22 \%, 1.67(1.47-1.91)$ & $33 \% / 36 \%, 0.90(0.78-1.04)$ \\
\hline PPV for $\geqslant C I N 3$ & $30 \% / 16 \%, 1.87(1.61-2.17)$ & $23 \% / 30 \%, 0.75(0.64-0.89)$ \\
\hline $23-29$ years & $3075 / 14299$ & $5310 / 3075$ \\
\hline$\geqslant$ ASCUS & 208/1066, 0.91 (0.79-1.05) & $435 / 208,1.21(1.03-1.42)$ \\
\hline CIN2 & $15 / 93,0.75(0.44-1.29)$ & $61 / 15,2.35(1.34-4.14)$ \\
\hline$\geqslant \mathrm{CIN} 3$ & $65 / 250,1.21(0.92-1.58)$ & $103 / 65,0.92(0.67-1.25)$ \\
\hline $\mathrm{CIN}$ treatments & $89 / 373,1.11(0.88-1.39)$ & $167 / 89,1.09(0.84-1.40)$ \\
\hline$<\mathrm{CIN} 2$ & $63 / 372,0.79(0.60-1.03)$ & $142 / 63,1.31(0.97-1.75)$ \\
\hline False positive for $\geqslant \mathrm{CIN} 2$ & $128 / 723,0.82(0.68-0.99)$ & $271 / 128,1.23(1.00-1.51)$ \\
\hline False positive for $\geqslant \mathrm{CIN} 3$ & $143 / 816,0.81(0.69-0.97)$ & $332 / 143,1.34(1.11-1.63)$ \\
\hline PPV for $\geqslant C I N 2$ & $38 \% / 32 \%, 1.20(0.99-1.45)$ & $38 \% / 38 \%, 0.98(0.79-1.21)$ \\
\hline PPV for $\geqslant \mathrm{CIN} 3$ & $31 \% / 23 \%, 1.33(1.06-1.68)$ & $24 \% / 31 \%, 0.76(0.58-0.99)$ \\
\hline 30-44 years & $9342 / 32819$ & $14370 / 9342$ \\
\hline$\geqslant$ ASCUS & $242 / 1435,0.59(0.52-0.68)$ & $472 / 242,1.27(1.09-1.48)$ \\
\hline CIN2 & $13 / 73,0.63(0.35-1.13)$ & $33 / 13,1.65(0.87-3.13)$ \\
\hline$\geqslant \mathrm{CIN} 3$ & $80 / 259,1.09$ (0.85-1.39) & $132 / 80,1.07(0.81-1.41)$ \\
\hline $\mathrm{CIN}$ treatments & $102 / 367,0.98(0.78-1.21)$ & $188 / 102,1.20(0.94-1.52)$ \\
\hline$<\mathrm{CIN} 2$ & $98 / 579,0.59(0.48-0.74)$ & $181 / 98,1.20(0.94-1.53)$ \\
\hline False positive for $\geqslant \mathrm{CIN} 2$ & $149 / 1103,0.47(0.40-0.56)$ & $307 / 149,1.34(1.10-1.63)$ \\
\hline False positive for $\geqslant \mathrm{CIN} 3$ & $162 / 1176,0.48(0.41-0.57)$ & $340 / 162,1.36(1.13-1.64)$ \\
\hline PPV for $\geqslant \mathrm{CIN} 2$ & $38 \% / 23 \%, 1.66(1.38-2.00)$ & $35 \% / 38 \%, 0.91(0.74-1.11)$ \\
\hline PPV for $\geqslant C I N 3$ & $33 \% / 18 \%, 1.83(1.48-2.26)$ & $28 \% / 33 \%, 0.85$ (0.67-1.07) \\
\hline $45-59$ years & $8504 / 27404$ & $13934 / 8504$ \\
\hline$\geqslant$ ASCUS & $86 / 922,0.30(0.24-0.37)$ & $180 / 86,1.28(0.99-1.65)$ \\
\hline CIN2 & $3 / 17,0.57(0.17-1.94)$ & $12 / 3,2.44(0.69-8.65)$ \\
\hline$\geqslant \mathrm{CIN} 3$ & $18 / 48,1.21(0.70-2.08)$ & $14 / 18,0.47(0.24-0.95)$ \\
\hline $\mathrm{CIN}$ treatments & $28 / 86,1.05(0.69-1.61)$ & $34 / 28,0.74(0.45-1.22)$ \\
\hline$<\mathrm{CIN} 2$ & $54 / 556,0.31(0.24-0.41)$ & $110 / 54,1.24(0.90-1.72)$ \\
\hline False positive for $\geqslant \mathrm{CIN} 2$ & $65 / 857,0.24(0.19-0.31)$ & $154 / 65,1.45$ (1.08-1.93) \\
\hline False positive for $\geqslant \mathrm{CIN} 3$ & $68 / 874,0.25(0.20-0.32)$ & $166 / 68,1.49(1.12-1.97)$ \\
\hline PPV for $\geqslant C I N 2$ & $24 \% / 7 \%, 3.46(2.23-5.38)$ & $14 \% / 24 \%, 0.59(0.35-0.99)$ \\
\hline PPV for $\geqslant C I N 3$ & $21 \% / 5 \%, 4.02(2.45-6.59)$ & $8 \% / 21 \%, 0.37(0.19-0.71)$ \\
\hline
\end{tabular}

